\title{
Notes
}

\section{Ethical Eating: Applying the Kosher Food Regulatory Regime to Organic Food}

\author{
Benjamin N. Gutman
}

[H]ow we eat determines, to a considerable extent, how the world is used.

-Wendell Berry ${ }^{1}$

Green products are red hot. ${ }^{2}$ This is the age of environmental consciousness, ${ }^{3}$ and consumers are using their purchasing power to support ecologically superior products and services. ${ }^{4}$ Information about the environmental impact of these products is essential to these choices; hence the rapid rise of ecolabeling as a form of green marketing. ${ }^{6}$ Whatever form

1. WENDELL BERRY, The Pleasures of Eating, in WHAT ARE PEOPLE FOR? 145, 149 (1990).

2. See James Salzman, Informing the Green Consumer: The Debate over the Use and Abuse of Environmental Labels, J. INDUS. ECOLOGY, Spring 1997, at 11, 12. But see Roger D. Wynne, The Emperor's New Eco-Logos?: A Critical Review of the Scientific Certification Systems Environmental Report Card and the Green Seal Certification Mark Programs, 14 VA. ENVTL. L.J. 51, 122 \& nn.294-97 (1994) (discussing the gap between what consumers say and what they do).

3. See Thomas C. Downs, Comment, "Environmentally Friendly" Product Advertising: Its Future Requires a New Regulatory Authority, 42 AM. U. L. REV. 155, 155 (1992); Roger D. Wynne, Note, Defining "Green": Toward Regulation of Environmental Marketing Claims, 24 U. MICH. J.L. REFORM 785, 785 (1991).

4. See Kimberly C. Cavanagh, It's a Lorax Kind of Market! But Is It a Sneetches Kind of Solution?: A Critical Review of Current Laissez-Faire Environmental Marketing Regulation, 9 VILL. ENVTL. L.J. 133, 133-34 (1998); see also JACQUELYN A. OTTMAN, GREEN MARKETING: OPPORTUNITY FOR INNOVATION 7 (2d ed. 1998) (discussing environmentally friendly products that were developed to satisfy consumer demand).

5. Ecolabels are a broad category of advertising claims about the environmental qualities of products. See Kristin Dawkins, Ecolabelling: Consumer Right-To-Know or Restrictive Business 
they take, ecolabeling programs share the goal of providing consumers with the information they need to make their purchases in accordance with their personal ethical views. ${ }^{7}$

Consumers need assurance that these labels truly identify the products that they wish to buy. Understandable concerns about deception, fraud, and confusion have led to greater government regulation of the form and content of ecolabels. In particular, both industry and environmental groups have increasingly called for uniform federal standards as a way to protect both manufacturers and consumers. ${ }^{8}$ A recent and controversial example is the federal government's decision to regulate the meaning of the term "organic" on food labels. The Department of Agriculture's proposed rule was heavily criticized for misunderstanding the nature of organic agriculture and was ultimately withdrawn.

In this Note, I argue that mandated uniformity is a poor regulatory policy for ethically based decisions, such as the choice to purchase organic food. "Organic" refers to a set of philosophical beliefs about our relationship with the environment, not merely to the physical characteristics of a product. Farmers and consumers, who grow or buy organic food for a variety of reasons, do not always agree on the best ways to implement their shared ethical commitments. Defining the precise "meaning" of organic through uniform regulations deprives these people of the right to make choices in harmony with their own beliefs.

Moreover, international trade law severely constrains the ability of governments to regulate products on the basis of their production methods. The Department of Agriculture's proposed organic rule likely violated free-

Practice?, in ENFORCING ENVIRONMENTAL STANDARDS: ECONOMIC MECHANISMS AS VIABLE MEANS? 501, 508 (Rüdiger Wolfrum ed., 1996).

6. See John M. Church, A Market Solution to Green Marketing: Some Lessons from the Economics of Information, 79 MiNN. L. REV. 245, 246 (1994).

7. Some of this information may also provide useful information about health or economic efficiency to consumers. The focus of this Note, however, is the ethical dimension of these choices. Purely self-interested motives do not fully explain these choices for all consumers. See infra note 18.

8. See, e.g., Jaime A. Grodsky, Certified Green: The Law and Future of Environmental Labeling, 10 YALE J. ON REG. 147, 165 (1993); see also Resource Conservation and Recovery Act Amendments of 1991: Hearings on S. 976 Before the Subcomm. on Envtl. Protection of the Senate Comm. on Env't and Pub. Works, 102d Cong. 14 (1991) (statement of Deborah A. Becker, Vice President, Envtl. Affairs, Kraft Gen. Foods) (calling for national environmental marketing guidelines); id. at 16 (statement of Linda Brown, Vice President, Green Cross Certification) (" $[T]$ here is an urgent need for Federal legislation to regulate environmental labeling claims."); id. at 18 (statement of Richard Denison, Senior Scientist, Envtl. Defense Fund) ("There is ... an urgent need for Federal action on environmental claims."); id. at 21 (statement of Rajeev G. Bal, President, Webster Indus.) ("[T]here should be national standards preempting the States."); $c f$. Georg a Richards, Note, Environmental Labeling of Consumer Products: The Need for International Harmonization of Standards Governing Third-Party Certification Programs, 7 GEO. INT'L ENVTL. L. REV. 235, 257-58 (1994) (discussing the pros and cons of international harmonization).

9. See infra Section II.B. 
trade agreements because it imposed unilateral, parochial restrictions on organic labeling. For these reasons, allowing heterogeneous definitions of organic may be superior to mandating a single, uniform definition.

If multiple standards are permitted, can they be policed effectively? I argue that kosher food, which must meet traditional Jewish legal requirements, provides a model for how heterogeneous standards can be maintained. ${ }^{10}$ Kosher, like organic, is a term that means different things to different people. To accommodate this pluralism, the religious Jewish community employs a sophisticated, privately driven labeling system to alert consumers to the kosher status of food. There is also an important role for public law enforcement in this regime, particularly trademark, mandatory disclosure, and fraud laws, and judicial enforcement of contracts. I conclude that the private-public hybrid ${ }^{11}$ developed in the kosher market should serve as a model for organic food and other ethically based ecolabels. At the very least, government regulations should not prevent private organizations from setting higher standards or producers from advertising this fact.

Sections I.A and I.B introduce organic and kosher foods, and explain that both are largely defined by production methods rather than physical characteristics. That attribute is shared by ecolabels more generally, which Section I.C briefly discusses. Sections II.A and II.B, respectively, describe government regulation of kosher and organic foods. Section II.C argues that some of these laws may violate international law, which does not generally allow distinctions to be made on the basis of production methods. Section III.A discusses the regulation of kosher food under a private-public hybrid model, and Section III.B considers whether a similar strategy could be applied to organic food. Part IV concludes that in both cases the market, not the government, should determine standards.

10. The similarity between kosher and organic food has been noted in passing before. See Dan L. Burk, The Milk Free Zone: Federal and Local Interests in Regulating Recombinant bST, 22 ColuM. J. ENVTL. L. 227, 307 n.460 (1997) ("In general, a rabbi's blessing will leave little physical evidence. Similarly, products labeled 'organic' or 'organically grown' are unlikely to display any detectable chemical or physical difference from conventionally produced products."); Talk of the Nation Science Friday (NPR broadcast, May 29, 1998), available in LEXIS, News Library, NPR File (statement of "Benny" from New York City) ("[W]hy should the government be involved in regulating whether something is organic or not?... [T] he government isn't involved whether certain food is Kosher ...."); Public Hearing on National Organic Standards Proposed Rule, Seattle, Wash. (Feb. 26, 1998) at 37 (statement of Gene Kahn) (transcript on file with The Yale Law Joumal) ("Organics is a way of life.... It's similar to observance of the Jewish dietary laws."); id. at 65 (statement of Yorum Bauman) ("[Y]ou would go and talk to a rabbi ... to find out what kosher means. And, in the same way, if you're going to find out what organic means ... you should talk to ... the people in this room."); id. at 212 (statement of Dave Stanford) ("Revitalize private standards organizations. The system of koshering food has worked very well."). None of these sources, however, analyze the analogy in any detail.

11. My use of this phrase should not be confused with Grodsky's "public-private hybrid model," which is not discussed in this Note. Grodsky, supra note 8, at 207. 


\section{ETHICAL EATING: ORGANIC AND KOSHER FOODS}

This Part explains the meaning of organic and kosher, and it argues that they share two important features. First, both are defined, at least in part, by the methods used to produce and process the food rather than the characteristics of the end product. Second, neither term admits of "a precise and universally acceptable definition." ${ }^{12}$ Organic farmers disagree about what particular farming methods are appropriate; similarly, rabbis disagree about whether particular foods are kosher. This Part concludes with a brief discussion of ecolabels more generally and suggests that their basis-life cycle analysis-also exhibits these two features.

\section{A. Organic Farming: An Ecological Ethic}

Ask a savvy consumer about organic food, and chances are that she will talk about eliminating pesticides, fertilizers, and other chemical residues from the finished product. ${ }^{13}$ Indeed, widespread skepticism about the efficacy of food safety regulations has spurred the demand for organic food. ${ }^{14}$ The perception is that organic food contains less carcinogenic residue and is grown with more care than conventional products. ${ }^{15}$ Although this may in fact be empirically true, ${ }^{16}$ it is not analytically necessary. ${ }^{17}$ Moreover, this definition of organic-as residue-free food-

12. I. Garth Youngberg \& Frederick H. Buttel, Public Policy and Socio-Political Factors Affecting the Future of Sustainable Farming Systems, in ORGANIC FARMING: CURRENT TECHNOLOGY AND ITS ROLE IN A SUSTAINABLE AGRICULTURE 167, 168 (D.F. Bezdicek et al. eds., 1984) [hereinafter ORGANIC FARMING] (referring to organic farming).

13. Cf. Richard R. Harwood, Organic Farming Research at the Rodale Research Center, in ORGANIC FARMING, supra note 12, at 1, 2 (noting the common assumption that "[o]rganic agriculture is merely conventional agriculture without the use of chemicals").

14. See, e.g., Gordon G. Bones, State and Federal Organic Food Certification Laws: Coming of Age?, 68 N.D. L. REV. 405, 405 \& n.2 (1992) (discussing the effects of the Alar scare on the demand for organic food). But $c f$. OLUF CHR. BøCKMAN ET AL., AGRICULTURE AND FERTILIZERS: FERTILIZERS IN PERSPECTIVE 212 (1990) ("The present problems [concerning food and health] derive from composition of the diet and amounts consumed, not from the way food is produced on farms.").

15. See Rick Franzen, Note, Will GATT Take a Bite out of the Organic Food Production Act of 1990?, 7 MinN. J. GLOBAL TRADE 399, 406-07 (1998).

16. See H. Vogtmann, Organic Farming Practices and Research in Europe, in ORGANIC FARMING, supra note 12 , at 19, 29-30 (citing a Swiss study showing no residue in nearly all organically grown food, but some residue in a significant portion of conventional food).

17. Natural and artificial substances, which may pose health risks, are present in the soil and water that organic farmers use but are beyond their control. It is possible that a careful and fortunate conventional farmer could produce safer food than an organic farmer. See S. REP. No. 101-357, at 299-300 (1990), reprinted in 1990 U.S.C.C.A.N. 4656, 4953-54. However, the accepted requirement that a field be organically managed for at least three years before being certified, see 7 U.S.C. $\$ 6504$ (2) (1994), may tend to lessen this possibility. Nevertheless, there is no accepted scientific evidence that organic food is compositionally different from conventionally produced food, see Terence J. Centner \& Kyle W. Lathrop, Differentiating Food Products: Organic Labeling Provisions Facilitate Consumer Choice, 1 DRAKE J. AGRIC. L. 30, 41 (1996), 
does not fully explain organic practices, many of which are rooted in a holistic ecological ethic encompassing the people, animals, plants, and land involved in food production. ${ }^{18}$

Consumers choose to buy organic food for both health and ethical reasons. ${ }^{19}$ As a result, organic food commands a substantial premium ${ }^{20}$ due to market factors and higher costs of production. ${ }^{21}$ In this country, organic farming has exploded into "one of the hottest megatrends in U.S. agribusiness," with annual sales in 1996 reaching $\$ 3.5$ billion. ${ }^{22}$ The industry has grown at a rate of twenty percent every year since $1990,{ }^{23}$ and it is predicted to quadruple in size over the next decade. ${ }^{24}$ Organic farmers

although many organic farmers and consumers continue to believe that it is, see, e.g., MASANOBU FUKUOKA, THE ONE-STRAW REVOLUTION: AN INTRODUCTION TO NATURAL FARMING 55-56 (Larry Korn ed. \& Chris Pearce et al. trans., Rodale Press 1978) (1975) ("If you show a rice plant from my field to a farmer he will know immediately... that chemical fertilizer was not applied."); Nancy Hobbs, They Taste Good, and They're Good for You, Too!, SALT LAKE TRIB., Oct. 14, 1998, at $\mathrm{Cl}$ (quoting a consumer as saying, "eating foods that aren't grown with ... all those chemicals [is] probabiy healthier. It just makes sense."). In practice, many programsincluding the proposed federal rule-require residue testing, but this is merely seen as a way to monitor compliance and discourage fraud. See, e.g., National Organic Program, 62 Fed. Reg. $65,850,65,932$ (1997) (proposed 7 C.F.R. $\$ 205.430$ (d)). In fact, this testing has been severely criticized by organic groups. See, e.g., Letter from Herve la Prarie, President of the International Federation of Organic Agriculture Movements, to Eileen S. Stommes, Deputy Administrator, Agricultural Marketing Service, U.S. Department of Agriculture 3 (Apr. 29, 1998) (on file with The Yale Law Journal) (hereinafter IFOAM Letter].

18. See Harwood, supra note 13, at 2. Like Congress, I take no position in this Note on whether organic food is "more healthful, nutritious, or flavorful" than non-organic food. S. REP. No. 101-357, at 293, reprinted in 1990 U.S.C.C.A.N. at 4947. In any event, health concerns alone cannot fully justify the organic movement. The growing popularity of organic clothing demonstrates this well. For example, Patagonia, a leading producer of high-quality outdoor clothing, converted its line to organic cotton in 1996, splitting the cost with consumers. See OTTMAN, supra note 4, at 201.

19. See Kyle W. Lathrop, Note, Pre-empting Apples with Oranges: Federal Regulation of Organic Food Labeling, 16 J. CORP. L. 885, 890 (1991). A Harris poll found that $84 \%$ of Americans wanted to purchase organically grown produce and half of them were willing to pay more for it. See S. REP. No. 101-357, at 289, reprinted in 1990 U.S.C.C.A.N. at 4943.

20. See Lathrop, supra note 19, at 893 n.72 (noting that organic food often sells for double the price of conventional food).

21. It is unclear whether organic farming is more or less economically efficient than conventional farming. Some of organic farming's currently higher costs of production may be due to the absence of economies of scale, see Youngberg \& Buttel, supra note 12, at 175; externalities, such as pollution costs, which conventional farming ignores, see John Bell Clark, Impact and Analysis of the U.S. Federal Organic Food Production Act of 1990 with Particular Reference to the Great Lakes, 26 U. ToL. L. REV. 323, 323 (1995); or increased labor costs to replace mechanical production, see Harold F. Breimyer, Economics of Farming Systems, in ORGANIC FARMING, supra note 12, at 163, 166. See also Franzen, supra note 15, at 402 (noting the market effects of low supply and high demand on organic prices). Evaluating the truth of these claims or their implications for social agricultural policies generally is beyond the scope of this Note.

22. See Bruce Ingersoll, Agricultural Department Proposes a Set of National Standards on Organic Foods, WALL ST. J., Dec. 16, 1997, at B6.

23. See Peter Hoffman, Going Organic, Clumsily, N.Y. TIMES, Mar. 24, 1998, at A23.

24. See Ingersoll, supra note 22, at B6. 
and consumers have created local, regional, and national organizations to foster education and cooperation. ${ }^{25}$

In this Section, I will briefly describe some of the techniques for raising organic crops and livestock, situating them within a larger ecological philosophy. I will then discuss some of the disputes within the organic community about particular practices.

\section{Organic Agriculture}

The organic movement has arisen largely as a reaction against conventional farming. ${ }^{26}$ Thus, in trying to define organic agriculture, it is useful to describe the salient characteristics of its conventional counterpart. Conventional agriculture relies heavily on chemical fertilizers and manure to restore the optimal chemical balance of the soil for particular crops. ${ }^{27}$ These products allow the farmer to sustain yields at a higher level than would otherwise be achievable, ${ }^{28}$ but they have the potential to cause serious pollution problems. ${ }^{29}$ Conventional practice also allows the use of chemical pesticides to control loss due to weeds, diseases, and animals. ${ }^{30}$ Many different products are available and regulated by federal and state

25. See National Organic Program, 62 Fed. Reg. 65,850, 65,914 (1997). Some link organic farming to small-scale production. See Youngberg \& Buttel, supra note 12, at 169. In their view, large-scale, specialized agriculture is at odds with the organic philosophy:

There is an ecology to a small dairy herd that is permanently broken when herd size increases. The small dairy farmer spreads manure on fields that produce feed crops for the cows. Large dairies in California, Florida, and Texas feed grain hauled in from Nebraska, Iowa, and Ohio. The animal waste must be impounded or trucked out, but it is never returned to the fields where the feed grain was grown. The nutrient cycle is broken, and the nitrogen rich dairy waste becomes a pollution problem.

PAUL B. THOMPSON, THE SPIRIT OF THE SOIL: AGRICULTURE AND ENVIRONMENTAL ETHICS 2 (1995). But see Youngberg \& Buttel, supra note 12, at 175 ("[O]rganic farming is not precluded on farms that are relatively large by U.S. standards.").

26. See generally NANCY JACK TODD \& JOHN TODD, BIOSHELTERS, OCEAN ARKS, CITY FARMING: ECOLOGY AS THE BASIS OF DESIGN 135-56 (1984) (describing the evolution of farming from prehistory to the present, and situating organic practices within it). As a selfconscious alternative to conventional farming, it can be traced back to at least the early part of this century. See RODALE'S ALL-NEW ENCYCLOPEDIA OF ORGANIC GARDENING 413-14 (Fern Marshall Bradley \& Barbara W. Ellis eds., 1992) [hereinafter ENCYCLOPEDIA]; WINFRIED SCHEEWE, NURTURING THE SOIL-FEEDING THE PEOPLE 79 (1993).

27. See BøCKMAN ET AL., supra note 14 , at $21,24,26$. Plants obtain many of the nutrients they need to grow by drawing on the soil's reserves. See id. at 17. Although there are a variety of natural processes by which depleted nutrients can be restored to the soil, the intensive agriculture that produces most of our food generally depletes these nutrients faster than they can be replenished. See id. at 192, 202.

28. See id. at 47.

29. See id. at 178-82 (mentioning air and water emission, solid waste, and occupational hazards as environmental impacts from fertilizer production); James Stephen Carpenter, Note, Farm Chemicals, Soil Erosion, and Sustainable Agriculture, 13 STAN. ENVTL. L.J. 190, 201-03 (1994) (discussing negative externalities to health associated with fertilizers).

30. See BØCKMAN ET AL., supra note 14 , at 50 . 
laww $^{31}$ but remain controversial due to concerns about ecological ${ }^{32}$ and human health effects, ${ }^{33}$ as well as the evolution of resistant strains of pests. ${ }^{34}$ The mainstream scientific and economic consensus is that in general, the benefits of these products-increased yield and lower food prices-outweigh their costs. ${ }^{35}$

The organic philosophy denies the dominant, instrumental view of nature that drives these practices. Its thetoric often evokes romantic images of traditional, simple methods. ${ }^{36}$ Most of its practices focus on achieving sustainability-not merely in the sense of a maximum sustainable yield but rather "ecologically sound, economically viable, socially just and humane." 37 These practices may in fact tend to minimize soil erosion and nutrient depletion, and they may therefore contribute to the long-term economic health of agriculture. ${ }^{38}$ Yet the underlying objective of the organic farmer is not simply optimizing productivity, but rather living in harmony with the natural order. ${ }^{39}$ Eliminating chemical fertilizers and pesticides is not necessarily the primary goal of organic farming, ${ }^{40}$ rather, it

31. See, e.g., Federal Insecticide, Fungicide, and Rodentcide Act, 7 U.S.C. $\S \S 136-136 y$ (1994); Connecticut Pesticide Control Act, CONN. GEN. STAT. \$§ 22a-46 to -66l (1997).

32. See, e.g., Carpenter, supra note 29, at 213-16 (discussing the costs of pesticide poisoning).

33. See, e.g., id. at 191-201 (discussing the health effects of pesticides, particularly on farm workers).

34. See, e.g., TODD \& TODD, supra note 26, at 143 ("Three-quarters of the insect pests in California are insecticide resistant.").

35. See Carpenter, supra note 29 , at 227. For the purposes of this Note, I am prepared to assume that this consensus is correct. But see id. at 226-34 (disputing the conventional wisdom).

36. See, e.g., WENDELl BERRY, THE UNSETTIING OF AMERICA: CULTURE \& AGRICULTURE 12 (1977) ("We have tried to escape the sweat and sorrow promised in Genesis-only to find that, in order to do so, we must forswear love and excellence, health and joy."). As one poet writes:

ploughs turn over upside down

degrade neglect the soil

without a feeling and no touch

as hoes and fingers did

tenderly and merciful

Al Imfeld, "Ploughs of Progress," quoted in SCHEEWE, supra note 26, at 26; cf. Bones, supra note 14, at $407 \mathrm{n.8}$ ("'Sustainable agriculture' and 'organic farming' are related terms but are not synonymous. Sustainable agriculture should not be confused with a return to primitive or nonindustrialized agriculture and the complete abolition of all agricultural chemicals.").

37. SCHEEWE, supra note 26, at 83 (quoting the definition of the International Federation of Organic Agriculture Movements). The organic philosophy is often situated within a broader framework of back-to-the-land consciousness, and supports the development of community-based agriculture cooperatives to replace national agribusiness corporations. See, e.g., BERRY, supra note 36 , at $13,194-95,221$.

38. See Carpenter, supra note 29, at 224-26.

39. Cf. Lori Schiraga, USDA Proposal Would Weaken Organic Standards Measure, L.A. TIMES, Mar. 15, 1998, at B19 ("Organic farming is based on a system of producing food and fiber in harmony with nature ....").

40. Many organic practitioners recognize that " [n]ot all synthetics are detrimental, and not all organics [i.e., natural substances] are beneficial" and that therefore each substance must be evaluated "on the basis of its long-term effects on the soil, our health, and the environment." Bones, supra note 14 , at 405 n.1. 
is "maximiz[ing] the health of the soil." 41 Added chemicals may be unnecessary and unhealthy ${ }^{42}$-instrumental reasons to eliminate them in many cases-but they also damage the environment and disrupt natural life cycles $^{43}$ - externalities whose costs are only considered within an intrinsic, ethical framework. In the words of Peter Hoffman, "Organic food is not just about a product; it is a philosophy in which the process of production is as important as the -final result." 44

This characterization is fairly abstract, but in the words of Secretary of Agriculture Dan Glickman, "[I]f you ask people to actually sit down and define what organic means, you get all kinds of different answers." 45 Organic farming has often been defined in the negative-that is, by reference to what organic farmers do not $\mathrm{do}^{46}$ The United States Department of Agriculture defined organic farming rather expansively:

[A] production system which avoids or largely excludes the use of synthetically compounded fertilizers, pesticides, growth regulators, and livestock feed additives. To the maximum extent feasible, organic farming systems rely upon crop rotations, crop residues, animal manures, legumes, green manures, off-farm organic wastes, mechanical cultivation, mineral-bearing rocks, and aspects of biological pest control to maintain soil productivity and tilth, to supply plant nutrients, and to control insects, weeds, and other pests. ${ }^{47}$

Others define "true" organic farming to exclude any use of synthetic and non-organically derived materials. ${ }^{48}$ The International Federation of Organic Agriculture Movements (IFOAM), a worldwide umbrella organization devoted to this issue, includes among the principal aims of organic farming "allow[ing] everyone involved in organic production and processing a quality of life conforming to the U.N. Human Rights Charter, to cover their basic needs and obtain an adequate return and satisfaction for their work, including a safe working environment" and "encourag[ing]

41. $I d$.

42. See Carpenter, supra note 29, at 191-203.

43. See id. at 210-19; IFOAM Letter, supra note 17, at 3.

44. Hoffman, supra note 23; see also S. REP. No. 101-357, at 292 (1990), reprinted in 1990 U.S.C.C.A.N. 4656, 4946 ("The 'organically produced' label ... pertains to the production methods used to produce the food rather than to the content of the food.").

45. All Things Considered: Organic Food Standards Announced (NPR radio broadcast, Dec. $15,1997)$, available in 1997 WL 12834710.

46. See ENCYCLOPEDIA, supra note 26, at 414.

47. U.S. DEP'T OF AGRIC., REPORT AND RECOMMENDATIONS ON ORGANIC FARMING 9 (1980) (emphases added).

48. See Clark, supra note 21 , at 326. 
organic farming associations to function along democratic lines and the principle of division of powers." 49

Thus, the organic philosophy constitutes a "continuum of attitudes and practices" rather than a concrete platform susceptible to absolute definition..$^{50}$ Its practitioners do share, however, the goal of using natural processes to the greatest extent possible. For example, many use natural predators, resistant crops, and intercropping instead of chemical pesticides to prevent widespread damage from pests. ${ }^{51}$ Rather than using synthetic fertilizers intensively, organic farmers compost, ${ }^{52}$ rotate crops, ${ }^{53}$ plant cover crops, ${ }^{54}$ and leave manure-both animal and green-on the fields to decompose instead of trucking it away or burning it. ${ }^{55}$ These methods are designed to prevent rapid depletion of the soil's natural nutrients. Most organic farmers also try to preserve the soil structure by minimizing the amount of plowing they do. ${ }^{56}$

\section{Organic Livestock}

Similar conclusions can be drawn from a comparison of conventional and organic practices with respect to livestock. Here too, the trend in modern agribusiness facilities is toward intensive, assembly-line production. ${ }^{57}$ Animals are generally confined to tiny cages and raised entirely in artificially controlled environments to maximize their size and productivity at the lowest cost. ${ }^{58}$ The squalor and barbarity of these operations has been well documented. ${ }^{59}$ Intensive production increasingly requires the use of high doses of antibiotics to control disease ${ }^{60}$ and

49. See IFOAM Letter, supra note 17 , at 4 .

50. Youngberg \& Buttel, supra note 12, at 168.

51. See Carpenter, supra note 29 , at 222.

52. See BøCKMAN ET AL., supra note 14 , at 194 ("Composting is an aerobic microbial process where the easily degradable organic substances are digested and converted to stable, slowly degradable organic matter. The process generates heat and thus kills most weed seeds and pathogens.").

53. Crop rotation "alternat[es] the types of crops grown in each field, rather than growing the same crop year after year which depletes the soil and provides a breeding ground for persistent pests." WHAT IS ORGANIC? (Stonyfield Farm Organic \& Organic Trade Ass'n eds., 1998) (on file with The Yale Law Journal).

54. Cover crops are planted between crops to replenish the soil's nutrients and to prevent weeds. See id.

55. See id. Green manure is crop "grown for use as decayable material" that is then plowed down into the soil. EDWARD H. FAULKNER, PLOWMAN's FOLLY 9 (1943).

56. See R.I. Papendick \& L.F. Elliott, Tillage and Cropping Systems for Erosion Control and Efficient Nutrient Utilization, in ORGANIC FARMING, supra note 12, at 69, 70-71.

57. See PETER SINGER, ANIMAL LIBERATION 96 ( $2 \mathrm{~d}$ ed. 1990).

58. See, e.g., id. at 99 (chickens), 123 (pigs), 130 (veal).

59. See generally JOHN BRYANT, FETTERED KINGDOMS 27-37 (rev. ed. 1990); ROBERT GARNER, ANIMALS, POLITICS, AND MORALITY 93-117 (1993); SINGER, supra note 57, at 95-157.

60. See Jim Mason, Brave New Farm?, in IN DEFENSE OF ANMALS 89, 99-100 (Peter Singer ed., 1985). 
hormones to stimulate growth. ${ }^{61}$ Poultry are often debeaked, ${ }^{62}$ and veal are so confined as to be physically unable to rotate their bodies. ${ }^{63}$ Most often, these facilities cannot accommodate in an ecologically sound and productive manner the huge volume of animal waste produced. To ship the manure to the fields where the feed was grown is generally not economically feasible, so it often ends up as a pollution problem rather than a useful nutrient source. ${ }^{64}$

Organic livestock practice avoids gratuitously using artificial processes such as antibiotics, and it requires the use of organic feed. ${ }^{65}$ It also emphasizes the importance of treating the animals humanely. ${ }^{66}$ Cattle are allowed to graze, and poultry are raised free-range. Organic operations are often less specialized and are peripheral to an agricultural farm that can provide feed and recycle wastes. ${ }^{67}$ As with crops, the organic philosophy dictates the use of processes that (potentially) affect the finished product in addition to those that simply comport with a broader ethic. ${ }^{68}$

\section{Disputes About Organic Practices}

Given the uncertainty that surrounds the meaning of organic, it is not surprising that there are disagreements about the acceptability of particular practices. Indeed, many practices, not all mutually consistent, are presented under the organic or alternative agriculture banner.

One dispute concerns "natural" pesticides and fertilizers. While some are comfortable using these, particularly when other methods fail, others believe more firmly that only naturally occurring processes should be used. ${ }^{69}$ Another difference arises over plowing and other soil-disrupting techniques. Plowing is seen in conventional settings as necessary to aerate

61. See SINGER, supra note 57, at 138 (describing the use of bovine growth hormones to increase cows' milk production).

62. See Mason, supra note 60 , at 93.

63. See SINGER, supra note 57, at 130.

64. Cf. BERRY, supra note 36 , at 90 ("If animals are regarded as machines, they are confined in pens removed from the source of their food, where their excrement becomes, instead of a fertilizer, first a 'waste' and then a pollutant.").

65. See Clark, supra note 21 , at 342-43.

66. See IFOAM Letter, supra note 17, at 4 (listing among the aims of organic farming, "[t]o give all livestock conditions of life which allow them to perform the basic aspects of their innate behavior").

67. Cf. Carpenter, supra note 29, at 223 ("The integration of crops and livestock makes possible sustainable practices. ... Erosion and the use of pesticides and inorganic fertilizers are reduced with these systems.").

68. See Schiraga, supra note 39, at B19 (arguing that organic livestock require organic feed and adequate space for movement).

69. Compare U.S. DEP'T OF AGRIC., supra note 47, at 9 (excluding only "synthetically compounded" materials), with Clark, supra note 21, at 336 (denying that natural pesticides may be used by "true" organic farmers). 
the soil and to allow strong root systems to form. ${ }^{70}$ Many alternative farmers avoid these methods, because they believe them to be wasteful ${ }^{11}$ and because they object to doing violence to the earth. ${ }^{72}$ Empirical evidence might play some role in resolving these disputes, but it is also possible that they indicate a fundamental split over ethical principles that does not admit rational solution.

A more significant divide exists between mainstream organic and biodynamic farming. The biodynamic movement is one of the historical antecedents of the modern organic movement and shares its holistic philosophy. ${ }^{73}$ In addition, however, it advocates the use of biodynamic preparations, specially composted recipes meant to "restore the soil's life force." 74 Particular emphasis is placed on the significance of spiritual forces for agricultural production. ${ }^{75}$ Unconventional techniques also address pest problems. ${ }^{76}$

Certified biodynamic products are highly regarded in the organic community because they comply with extremely strict standards, ${ }^{77}$ and in fact command a premium over ordinary organic food. ${ }^{78}$ Biodynamic farming is particularly concerned with promoting self-sufficiency and

70. See BøCKMAN ET AL., supra note 14, at 84 .

71. See, e.g., L.F. Elliott et al., Summary of the Organic Farming Symposium, in ORGanic FARMING, supra note 12, at 187, 191 (noting that plowing wastes energy and destroys the soil's organic matter).

72. See SCHEEWE, supra note 26, at 81-82 (“[N]atural agriculture means no plowing . . . [U]sing violence against nature causes human beings to have more hardship, to be tense and to lead unnatural lives.").

73. See id. It was founded in the 1920 s by Rudolf Steiner. See Letter from Anne Mendenhall, Director, Demeter Association, to Eileen S. Stommes, Deputy Administrator, Agricultural Marketing Service, U.S. Department of Agriculture 1 (Apr. 27, 1998) (on file with The Yale Law Journal) [hereinafter Demeter Letter].

74. Miles Corwin, One Step Beyond Organic, L.A. TMES, Dec. 4, 1989, at A1. One method is to bury a cow hom filled with manure at the fall equinox; in spring the manure is dug up, mixed into water in a particular swirling pattern, warmed to human body temperature, and then sprayed on fields. See id.

75. See id. Advocates follow the astrological "cosmic rhythms," arguing, for example, that leaf crops such as lettuce "should be planted when the moon is in a water sign such as Pisces or Scorpio." Id. Crops are often sowed two days before a full moon to "exploit its gravitational pull." Sonia L. Nazario, Are Organic Foods Spiritual Enough? Not for Everyone-Biodynamic Farmers Employ Exotic Compost in Quest for Health and Harmony, WALL ST. J., July 21, 1989, at Al.

76. For example, when snails attacked one practitioner's lettuce crop, "on a foggy morning during a full moon, she collected five gallons of the slimy creatures, threw them into a pot of water and stewed them for a month." Id. Apparently, this solution worked. See id.

77. See Mindy Pennypacker, Habitat-Saving Habit, SreRRA, Mar. 1997, at 18, 19 listing Demeter as one of four "reputable certifiers"); Letter from Aleen Rothschild-Seidel, on behalf of Demeter Association, to Eileen S. Stommes, Deputy Administrator, Agricultural Marketing Service, U.S. Department of Agriculture 2 (Apr. 28, 1998) (on file with The Yale Law Journal) ("Demeter certified products have a reputation in the organic community nationally and internationally for being high-quality natural goods produced according to strict standards; the Demeter community is known for being philosophically committed to the natural biodynamic process.").

78. Corwin, supra note 74. 
community-supported agriculture. ${ }^{79}$ Most organic food, however, is not biodynamically grown: "Biodynamic farming makes ordinary organic farming look about as spiritual as strip-mining." 80

In sum, while there is no consensus about the precise meaning of the term, "organic" generally refers to a way of producing a food, rather than a claim about its physical attributes. Organic agriculture may be concerned with a wide range of impacts, from the depletion of the soil's nutrients to the treatment of the people and animals involved in production.

\section{B. Kosher Food: Spirituality in Everyday Life}

Kashrut ${ }^{81}$ presents an analogous situation to organic food: It is based on production and processing methods rather than product standards, and it is subject to differing interpretations. In this Section, I introduce some aspects of kashrut, and describe several well-known disputes within the Jewish community about particular products.

The market for kosher food is also hot. ${ }^{82}$ Sales grew by twelve to fourteen percent every year from 1992 to $1997,{ }^{83}$ and some estimate the industry to be as large as $\$ 47$ billion a year. ${ }^{84}$ Seven million people regularly purchase kosher food in this country, and over 36,000 products are available. ${ }^{85}$ Interestingly, less than a third of these kosher consumers are Jewish. ${ }^{36}$ Most significantly, many mainstream foods-from Tropicana orange juice ${ }^{87}$ to Oreo cookies $^{88}$-are now under kosher supervision.

79. See id.; see also Paul Rauber, Money Where Your Mouth Is, SIERRA, July-Aug. 1995, at 16 (referring to the BioDynamic Farming and Gardening Association as "the country's leading promoter" of community-supported agriculture).

80. Nazario, supra note 75; see also Demeter Letter, supra note 73, at 1 (claiming that "biodynamic agriculture is distinctly different from organic agriculture" and "cannot be considered as only a variation" of it).

81. Kashrut is the Hebrew word for the entire body of Jewish dietary law. It derives from the Hebrew kasher, which is the source of the English "kosher." See 6 ENCYCLOPAEDIA JUDAICA 26 (1972). Because of differences in pronunciation and transliteration conventions, the word may also be spelled kashrus or kashruth.

82. See Joe M. Regenstein \& Carrie E. Regenstein, Looking in on Kosher Supervision of the Food Industry, 39 JUDAISM 408, 408 (1990) (detailing the growth of the kosher food market).

83. See Kosherfest' '98, SUPERMARKET NEwS, Nov. 30, 1998, at 19.

84. See id.

85. See Frank Bruni, The Brave New World of Kosher, N.Y. TIMES, Nov. 15, 1996, at B1.

86. See id.

87. See Randi Feigenbaum, Symbolic Legal Battle: Dispute Between Kosher-Certification Agencies Triggers Lawsuit, JEWISH EXPONENT, Mar. 27, 1997, at 20.

88. See Joshua J. Hammerman, The Forbidden Oreo, N.Y. TIMES, Jan. 11, 1998, § 6 (Magazine), at 66. 


\section{An Overview of Kashrut}

Contrary to popular belief, kosher food has not been blessed by a rabbi. ${ }^{89}$ Nor is kashrut designed to protect health. ${ }^{90}$ Rather, eating only kosher food is seen as a way of elevating oneself spiritually. ${ }^{91}$ Although kashrut is often thought to be no more than a prohibition against pork, shellfish, and mixing meat and milk, it is a complex and detailed set of precepts.

The rules of kashrut, like most Jewish law, derive from both biblical sources $^{92}$ and traditional rabbinical writings. ${ }^{93}$ They can be loosely categorized as product-based or process-based, although the two are often intertwined. The principal product-based laws are those forbidding certain foods or combinations of foods. Of animals, only certain mammals, ${ }^{94}$ birds, ${ }^{95}$ and fish ${ }^{96}$ may be eaten. ${ }^{97}$ Blood is categorically forbidden, ${ }^{98}$ as are

89. Cf., e.g., Mark A. Berman, Kosher Fraud Statutes and the Establishment Clause: Are They Kosher?, 26 COLUM. J.L. \& SOC. PROBS. 1, 1 (1992) ("The dairy ran out of 'Kosher for Passover' labels but I assure you that the rabbi was here yesterday and blessed all the milk.").

90. See, e.g., ELI W. SCHLOSSBERG, THE WORLD OF ORTHODOX JUDAISM 55 (1996) ("The food itself may contain considerably more than a grain of salt, plus cholesterol, saturated fats, additives, and calories.... The Higher Authority does not guarantee either the nutritional acceptability or the healthfulness of a product that meets every religious requirement of the kosher laws."); Berman, supra note 89, at 4 ("Kosher doesn't taste any better; kosher isn't healthier; kosher doesn't have less salmonella. Religion is not based on logic." (quoting the head of New York State's Kosher Enforcement Bureau)). Some writers have suggested that the development of kashrut could be explained on health grounds. See, e.g., JAMES TOWNLEY, THE REASONS OF THE LAWS OF MOSES FROM THE "MORE NEVOCHIM" OF MAIMONIDES 304-05 (London, Longmon, Rees, Orme, Brown, \& Green 1827) ("[A]ll those kinds of food which are forbidden in our law[] are unwholesome ... For the flesh of swine is of too humid a nature to be wholesome ... The Fat of the Intestines ... clogs the stomach too much, hinders digestion, and generates thick and cold blood ....").

91. See SCHLOSSBERG, supra note 90, at 54 ("Orthodox Jews eat kosher food because it is good for their souls."). For an interesting discussion about the ecology of kashrut, see Catherine Beth Sullivan, Comment, Are Kosher Food Laws Constitutionally Kosher?, 21 B.C. ENVTL. AFF. L. REV. 201, 207-08 (1993).

92. See, e.g., Exodus 34:26 (meat and milk); Leviticus 7:26 (blood); Leviticus 11:1-44 (animals); Leviticus 22:8 (slaughtering).

93. See, e.g., BabYlonian TALMUd, TRACTATE Hullin 115b (meat and milk); BABYLONIAN TALMUD, TRACTATE ABODAH ZARAH 30a (wine). For a more general discussion of the roots of Jewish philosophy and practice, see Maimon Schwarzschild, Pluralist Interpretation: From Religion to the First Amendment, 7 J. CONTEMP. LEGAL IsSUES 447, 450-57 (1996).

94. Mammals must both chew their cud and have split hooves in order to be kosher. Thus, cows and deer may be kosher, but pigs (and hence pork, bacon, and ham) are not. See Leviticus 11:3-7.

95. Birds of prey are prohibited. Chicken, geese, and other domesticated poultry are permitted. Because the Bible does not give biological criteria for identifying kosher and nonkosher birds, most authorities agree that only those birds that have a tradition "through the generations" of being eaten may be considered kosher. See YACOV LIPSCHUTZ, KASHRUTH 18-19 (1988). For a discussion of the controversy over the status of turkey, see Gerald F. Masoudi, Comment, Kosher Food Regulation and the Religion Clauses of the First Amendment, $60 \mathrm{U}$. CHI. L. REV. 667, 670 (1993).

96. Fish must have fins and scales to be considered kosher. See Leviticus 11:9-12. For example, tuna and salmon are acceptable; excluded are shark, shellfish, and, according to Orthodox authorities, sturgeon and swordfish. Conservative authorities consider the latter two, 
certain fats. ${ }^{99}$ Also strictly prohibited is mixing meat and dairy products. ${ }^{100}$ Finally, special rules are followed on the holiday of Passover, when leavened products may not be consumed. ${ }^{101}$

Process-based laws generally concern either the method of preparation or the identity of those preparing the food. The former includes the rules regarding the preparation of meat. Meat and poultry must be slaughtered in a particular manner ${ }^{102}$ and then checked for signs of disease on the internal organs. ${ }^{103}$ In addition, the utensils and other equipment must be unused or ritually cleansed before being used for kosher cooking. ${ }^{104}$ Laws governing associations with Gentiles tend to be more controversial and less universally observed. ${ }^{105}$ Among these requirements are restrictions on

which have scales as juveniles but shed them at maturity, to be kosher. In England, Orthodox Sephardic Jews accept sturgeon as kosher. See Berman, supra note 89, at 8-9.

97. The Bible also identifies certain species of locust that may be eaten. See Leviticus 11:2023. However, the precise method of identifying the kosher species has been forgotten, and today insects are generally not considered kosher. This prohibition leads to various inspection requirements for vegetables. See E. EIDLITZ, Is IT KOSHER? 195-97 (1992) (detailing inspection guidelines for various vegetables). In fact, the movement toward organic and low-input agricultures, which tolerate more insects in the food supply, has exacerbated this problem. See Regenstein \& Regenstein, supra note 82, at 410.

98. See Leviticus 7:26. This law has lead to process-based rules to ensure the elimination of blood. Most meats are salted and soaked. See generally LIPSCHUTZ, supra note 95, at 30-39. Liver, which has the highest concentration of blood, must be seared by an open flame. See Sheryl Julian, What? Kosher Foie Gras?, Boston GLOBE, Apr. 8, 1998, at E1 ("[S]he flipped the liver, left it for several seconds, then pulled it off the flame.... The rabbi examined it to be sure it was browned and pronounced the foie gras just right. He speculated that this was one of the only times 'in the history of the world that foie gras was koshered."').

99. See Leviticus 7:22-25; Menachem Genack, Industrial Kashrut Supervision, 39 JUDAISM 402,406 (1990).

100. See Deuteronomy 14:21. This rule has been strengthened: Meat and dairy foods are not even eaten at the same meal, although the precise degree of temporal separation required varies by local custom. See LIPSCHUTZ, supra note 95, at 42-43. For these reasons, certified kosher products are often labeled "meat," "dairy," or "parve" (meaning neither meat nor dairy).

101. See Exodus 13:3, 6. Certain grains become leavened (or risen) when they come into contact with water more than 18 minutes before baking. See SCHLOSSBERG, supra note 90, at 32 . For this reason, only specially prepared flatbread called matzoh is consumed on Passover. See id.

102. The trachea, esophagus, carotid arteries, and jugular veins must all be severed simultaneously with one stroke of a very sharp and smooth knife. See Berel Berkovits, Challenges to Shehitah in Europe, 39 JUDAISM 470, 470 (1990).

103. Although certain adhesions on the lungs are considered permissible by most, meat labeled glatt (Yiddish for "smooth") is certified as free from any adhesions, and some Jews choose to eat only glatt meat. See Genack, supra note 99 , at 406 .

104. The laws of "kashering" utensils are complicated. Most metal utensils, for examples, need to be boiled, but some must come into contact with fire. See Gedalia Dov Schwartz, Kashruth-Problems and Solutions, 39 JUDAISM 427, 429-33 (1990).

105. In part, this may be due to the fact that they do not derive from Biblical sources, but rather were instituted in the Talmudic period as part of a general campaign of separatism in order to safeguard Biblical prohibitions. See BABYLONIAN TALMUD, TRACTATE ABODAH ZARAH 36b; cf. Kent Greenawalt, Religious Law and Civil Law, 71 S. CAL. L. REV. 781, 801 n.79 (1998) ("DD]ifferent attitudes toward mingling with nonJews are tied to disagreements over the stringency of kosher laws, with Conservative Jews preferring more contact than Orthodox Jews."). 
Gentile-handled wine ${ }^{106}$ and Gentile-cooked food. ${ }^{107}$ On the other hand, leavened food owned by a Jew during Passover is not considered kosher even after the holiday. ${ }^{108}$

\section{Kashrut Disputes}

In interpreting the traditional sources of Jewish law and custom, each community is guided by the legal decisions of its scholars, generally rabbis. ${ }^{109}$ There is no supreme authority to resolve any disputes that arise; this "interpretive pluralism" allows multiple religious cultures to coexist. ${ }^{110}$ Perhaps the most prominent divergences in interpretation are those between the Ashkenazic and Sephardic ${ }^{111}$ communities and the Orthodox ${ }^{112}$ and

106. Gentile wine was prohibited because of the fear that it might have been used in idolatrous ceremonies. See Odelia E. Alroy, Kosher Wine, 39 JUDAISM 452, 452-53 (1990). Some would extend the prohibition to wine handled by non-observant Jews. See id. at 454 . Boiled wine, however, was permitted because it was considered unfit for idolatrous purposes. See id. at 455 . Today, certified kosher wine is either mevushal (raised to a high temperature) or handled only by. observant Jews until bottling. Id. It should be noted that different communities disagree about how high the temperature must be raised for wine to become mevushal: The Union of Orthodox Jewish Congregations of America requires a minimum of $168^{\circ} \mathrm{F}$, but the Lubavitch Hassidic movement requires it to reach $190^{\circ} \mathrm{F}$. See $i d$. at 456 . Similar restrictions are observed with other grape products. See $i d$. at 453 . The Conservative movement does not adhere to these requirements, except for wine used in sacramental rituals, because of the general absence of idolatrous practices in this country. See id. at 457-59.

107. Most authorities require only that some part of the cooking be done by a Jew. As a matter of practice, many kashrut supervisors consider it sufficient for them to light the pilot flame for gas stoves and ovens. See LIPSCHUTZ, supra note 95, at 69-70. Some adhere to stricter requirements with breads and milk. See, e.g., 1 SHOLOM YEHUDA GROSS, KOSHER MIIK IN ACCORDANCE WTTH JEWISH LAW passim (1981) (arguing that the milk of Gentiles is forbidden).

108. BABYLONIAN TALMUD, TRACTATE PESAHIM 29a. This leads to the common practice of "selling" one's not-kosher-for-Passover food to a Gentile prior to the holiday, to be repurchased afterwards. See EIDLITZ, supra note 97, at 91.

109. See Greenawalt, supra note 105 , at 786-87. However, some rabbis, acknowledged for their great wisdom and learning, may be followed by many different communities. For example, Moshe Feinstein's rulings on issues of Jewish law are widely accepted throughout the Orthodox Ashkenazic world. See, e.g., 1 GRoss, supra note 107, at 63; Berman, supra note 89, at 8. Unlike spiritual leaders in some religions, rabbis do not serve a ritual purpose. Rather, as trained scholars of Jewish law, their role is to issue legal rulings on difficult issues.

110. See Schwarzschild, supra note 93, at 457; see also Greenawalt, supra note 105, at 786. However, the Orthodox approach to precedent is highly deferential to earlier decisions, whereas Conservative philosophy accepts that precedent may be reconsidered in the light of changed circumstances. See Mordecai Waxman, Conservation Judaism-A Survey, in TradITION AND Change: The Development of CONSERVATIVE JudAisM 3, 20 (Mordecai Waxman ed., 1958) ("Orthodoxy has ... [in] recent generations rejected the right to any but minor interpretations. ... Conservative Judaism holds itself bound by the Jewish legal tradition, but asserts the right . . . to interpret and to apply Jewish law.").

111. Ashkenazic (literally, German) Jews are of Eastern European origin, and make up the vast majority of American Jews. Sephardic (literally, Spanish) Jews are generally of Middle Eastern and North African origin. A narrow majority of Israeli Jews are Sephardic, but they make up only a small minority of American Jews. For a brief overview of the historical and philosophical split between the Ashkenazic and Sephardic communities, see Berman, supra note 89 , at 9 n.37; and Schwarzschild, supra note 93, at 457. 
Conservative ${ }^{113}$ movements in this country. ${ }^{114}$ Although particular cases of concrete disputes abound, ${ }^{115}$ I will focus here on two examples: gelatin, and legumes during Passover.

New food-processing technologies often present particular difficulties for kashrut experts. ${ }^{116}$ Gelatin is no exception. It is a thickening agent used to make Jello, marshmallows, gel capsules, and a wide variety of other products. Gelatin is an animal byproduct, generally derived from cows or pigs. ${ }^{117}$ Because it is highly processed, it is unclear whether kashrut requires that it be obtained from kosher, properly slaughtered animals, and furthermore whether it remains a meat product (and therefore not usable with dairy). The vast majority of kashrut supervisors in this country do not permit any gelatin. ${ }^{118}$ However, the Israeli rabbinate allows the use of beef gelatin, ${ }^{119}$ and a few Orthodox rabbis in this country even permit the use of pork gelatin. ${ }^{120}$ Most Conservative rabbis accept all gelatins. ${ }^{121}$

112. Orthodox Judaism adopts a highly traditional and legalistic approach to Jewish law. See Berman, supra note 89, at 7. The label covers a wide variety of groups from the Modern Orthodox movement, which seeks to integrate very traditional Jewish practice into secular life, to Hassidic sects, which tend to favor more separate, closed communities.

113. Conservative Judaism encourages the evolution of traditional practice to fit a modem, secular life. See id. For example, in the light of society's changing conceptions of gender roles, women have gained greater access to participation in traditional rituals.

114. There are other significant movements in this country, such as Reform and Reconstructionist Judaism, but these groups generally do not accept the binding nature of traditional Jewish law in general, and kashrut in particular. See Peter S. Knobel, Reform Judaism and Kashrut, 39 JUDAISM 488, 488 (1990). But see Greenawalt, supra note 105, at 786 n.25 ("In practice, Reconstructionist Jews often follow kosher guidelines to some extent for the spiritual values they believe doing so entails.... But even those who keep kosher are not as concerned about technicalities as Orthodox people would be."); John Dart, Reform Rabbis Will Consider Return to Kosher Dietary Laws, L.A. TMMES, Dec. 6, 1997, at B11. A full accounting of Jewish religious cultures would also include discussion of Hassidic and other ultra-Orthodox sects.

115. See, e.g., supra notes 96 (swordfish and sturgeon), 103 (glatt meat), 106 (wine), \& 107 (milk and bread).

116. See Schwartz, supra note 104, at 427 (noting that rabbinical guidance is needed to reflect technological change). Of course, new scientific knowledge may also help supervisors ensure the kashrut of foods, see, e.g., Regenstein \& Regenstein, supra note 82, at 413 (discussing the use of mass spectroscopy to determine the source of vinegar), and provide new choices for consumers, see, e.g., id. at 414 (discussing the possibility of using genetically engineered rennin to produce kosher cheeses).

117. Gelatin is extracted from the bones and hides of animals by soaking them in various acids and bases over a long period of time. See EmLITZ, supra note 97, at 93. Gelatin could also be made from fish skins, which would present fewer kashrut problems than beef or pork gelatin. See Regenstein \& Regenstein, supra note 82, at 410.

118. See Regenstein \& Regenstein, supra note 82 , at 410.

119. See id.; see also DAVID I. SHEINKOPF, ISSUES IN JEWISH DIETARY LAWS: GELATIN, KITNIYYOT, AND THEIR DERIVATIVES 7-92 (1988) (arguing that gelatin from kosher animals, even if not properly slaughtered, is kosher and parve).

120. See Regenstein \& Regenstein, supra note 82, at 410.

121. In the early part of this century, Orthodox rabbis also accepted gelatin without qualification. See SHEINKOPF, supra note 119, at 10-12. By 1966, major Orthodox authorities had restricted kosher gelatin to that derived from kosher meats, which caused the leading certification organizations to prohibit its use. See EDLITZ, supra note 97, at 93. 
Legumes present a difference that arises not from a dispute over the technical requirements of kashrut, but from historical practices that have become enshrined in the customary law of certain communities. ${ }^{122}$ Ashkenazic Jews avoid certain legumes ${ }^{123}$ and rice during Passover ${ }^{124}$ because they were traditionally stored together with (Biblically) prohibited grains. Sephardic Jews, on the other hand, have no such tradition and therefore consume these legumes. ${ }^{125}$ As a practical matter, this difference leads to two separate meanings of "kosher for Passover."

To conclude, kosher food is another example of a largely process-based category. As with organic food, there is a lack of consensus about the precise meaning of "kosher." Similarly, a broad range of concerns about tradition, community, and morality can be subsumed under the kashrut banner.

\section{Ecolabels More Generally}

The problems in defining kosher and organic foods are analogous to those of setting standards for many ecolabels. Although some organic and kosher practices directly affect the physical attributes of finished products, ${ }^{126}$ the vast majority of their rules address ethical concerns about the way food is produced. Similarly, the basic tool of many ecolabeling programs is life-cycle analysis, ${ }^{127}$ a cradle-to-grave assessment of all of the environmental impacts of a product. ${ }^{128}$ This analysis encompasses externalities not reflected by market prices. ${ }^{129}$ Relevant considerations include the product's raw materials, production processes, use, and disposal. ${ }^{130}$ Thus, life-cycle analysis, like kosher and organic standards, is concerned with production and processing methods.

The holistic vision of life-cycle analysis is somewhat aspirational. Although life-cycle analysis highlights the need to consider tradeoffs,

122. Customary practices may gain the status of religious law. See SCHLOSSBERG, supra note 90 , at 9.

123. In particular, they shun most varieties of beans. For a list of prohibited legumes and grains, see Joe Regenstein \& Carrie Regenstein, Looking in, KASHRUS MAG., Apr. 1995, at 49, 51-52.

124. See Genack, supra note 99 , at 402.

125. See id.

126. For example, an organic farmer not using chemical pesticides is likely to produce food with lower pesticide residue. See supra note 17. Of the kashrut examples discussed above, the controversies over gelatin, glatt meat, wine, milk, and bread all concern methods; the disputes about fish and legumes deal with products.

127. See Salzman, supra note 2, at 12. But see Church, supra note 6, at 259 (criticizing recent green advertising for focusing exclusively on waste issues).

128. See Peter S. Menell, Structuring a Market-Oriented Federal Eco-Information Policy, 54 MD. L. REV. 1435, 1436 (1995).

129. See id. at 1443.

130. See Amy Lynn Salzhauer, Obstacles and Opportunities for a Consumer Ecolabel, ENVIRONMENT, Nov. 1991, at 10, 13. 
difficulties in gathering and quantifying data limit its utility as a definitive environmental measure. ${ }^{131}$ Its inherent uncertainty allows for the possibility of interest group capture. ${ }^{132}$ As a result, particular analyses are often disputed. For example, an analysis by the National Association of Diaper Services (cleaners of cloth diapers) concluded that cloth diapers have less impact on the environment than disposables, but one commissioned by Procter and Gamble (a manufacturer of disposable diapers) purported to show that disposables are no worse than cloth. ${ }^{133}$ Consumer Reports, after identifying the divergent assumptions employed by each side, suggested that the choice be made on the basis of local environmental conditions. ${ }^{134}$ The difficulties are not merely academic; policy decisions are often made on the basis of these life cycle analyses. ${ }^{135}$

Ecolabels come in a variety of forms. They can be mandatory or voluntary, single-attribute or multi-criteria, and binary or graded. ${ }^{136}$ Voluntary programs may be government sponsored or privately run. ${ }^{137}$ Both organic and kosher certification programs would be classified as voluntary, multi-criteria, binary labels, so I focus on that category in this Note.

\section{GOVERNMENT REGULATION OF KOSHER AND ORGANIC STANDARDS}

The market premium commanded by kosher food creates a strong temptation, in the absence of external checks, to pass off non-kosher food as kosher. ${ }^{138}$ The same is true for organic food. ${ }^{139}$ In addition, because both

131. See Church, supra note 6, at 261-63; Dawkins, supra note 5, at 504; Grodsky, supra note 8, at 221-24.

132. See Church, supra note 6, at 263.

133. See Planet Watch: Which are Best for the Environment?, 56 CONSUMER REP. 555 (1991).

134. See id. For example, the landfill scarcity in the northeast disfavors bulky disposable diapers; conversely, the water shortage in the southwest disfavors cloth diapers, whose cleaning makes intensive use of (and pollutes) water resources. See id.

135. See generally Church, supra note 6, at 264 (noting that in response to the disposable diaper situation, "state legislatures proposed drastic measures, including diaper taxes, warning labels, and outright bans").

136. See Elliot B. Staffin, Trade Barrier or Trade Boon? A Critical Evaluation of Environmental Labeling and Its Role in the "Greening" of World Trade, 21 CoLUM. J. ENVTL. L. 205, 211 (1996). Staffin refers to "negative content" and "content neutral" labels, rather than binary or graded. I use the more general terms to facilitate comparison with kosher and organic foods, which are generally "positive content" labels.

137. Id. at 220. The leading private multi-criteria ecolabel in this country is the Green Seal, founded in 1989. See Cavanagh, supra note 4, at 201. For a critical review of the program, see Wynne, supra note 2 , at 51 .

138. New York became the first state to regulate kashrut in 1915, in response to the failure of the newly appointed communal chief rabbi to solve the problems created by the "charlatans, profiteers and outright crooks" who were running the kashrut industry. See Marc D. Stern, Kosher Food and the Law, 39 JUDAISM 389, 389 (1990). Interestingly, this law also failed to solve the problem, at least with respect to the slaughter of poultry, leading to the incorporation of the Kashruth Association to certify poultry privately. See id. at 392. 
categories are defined by production and processing methods, it is generally difficult or impossible for consumers to evaluate directly the truthfulness of a producer's claims. ${ }^{140}$ This situation has led federal and state governments to enact laws designed to protect consumers. In Sections II.A and II.B, I describe the existing laws against kosher and organic fraud. I argue in Section II.C, however, that many of these laws may violate international trade law, which requires tolerance of heterogeneous production methods. I conclude that these laws do not suffice to protect consumers of kosher and organic foods.

\section{A. Kosher Fraud Laws}

At least twenty-two states have statutes prohibiting the fraudulent representation of non-kosher food as kosher. ${ }^{141}$ Most of these statutes define kosher as "prepared or processed in accordance with orthodox Hebrew religious requirements," ${ }^{142}$ and mandate various disclosure requirements ${ }^{143}$ and enforcement mechanisms. ${ }^{144}$ In 1925 , a unanimous ${ }^{145}$ Supreme Court upheld New York's kosher fraud law against a vagueness challenge. ${ }^{146}$ Of course, that decision was handed down before the Court had decided that

139. See S. REP. No. 101-357, at $289-90$ (1990), reprinted in 1990 U.S.C.C.A.N. 4656, 494344 (noting the "growing evidence that some conventionally grown food is deliberately mislabeled as 'organic' by dishonest traders looking to cash in on the premium prices organic food commands"); Bones, supra note 14, at 411 n.29 (claiming that supporters of California's regulations point to the opportunities for "fraud and misrepresentation"); $c f$. Ingersoll, supra note 22 , at B6 ("The proposed standards are likely to force many food processors to reformulate entire product lines and revise their labeling and marketing claims. "A lot of them have been getting a premium for products that are half-organic or less ...." (quoting Kathleen Merrigan, National Organic Standards Board)).

140. Cf. Grodsky, supra note 8, at 150 (discussing the same problem with ecolabels).

141. See Karen Ruth Lavy Lindsay, Comment, Can Kosher Fraud Statutes Pass the Lemon Test?: The Constitutionality of Current and Proposed Statutes, 23 U. DAYTON L. REv. 337, 344 \& n.58 (1998) (listing statutes). Until recently, a federal regulation also provided the informal view of the FDA that "kosher should only be used on food products that meet certain religious dietary requirements." See Labeling of Kosher and Kosher-Style Foods, 21 C.F.R. § 101.29 (1997), revoked by Food and Cosmetic Labeling; Revocation of Certain Regulations, 62 Fed. Reg. $43,071,43,072$ (1997). In addition, a number of municipalities have ordinances on kashrut. See Lindsay, supra, at 344 \& n.58.

142. Lindsay, supra note 141 , at 345 . Some states omit the reference to the Orthodox. $I d$. at 346. California has a more complex definition, requiring that "every Jewish law and custom" be followed at all stages of production. Id. at 345 n.64. New Jersey's law, passed after the prior law was held to violate the First Amendment, see infra note 215 and accompanying text, does not define kashrut at all. See Lindsay, supra note 141, at 346.

143. For example, under Connecticut law, sellers of both kosher and non-kosher meats must post signs in the window and over the meats declaring which type they sell. CONN. GEN. STAT. § 53-317(a) (1994).

144. All these state laws provide for criminal penalties. See Lindsay, supra note 141, at 346. Some also allow civil actions, including private causes of action. See $i d$.

145. Justice Brandeis took no part in the case. See Hygrade Provision Co. v. Sherman, 266 U.S. 497, 503 (1925).

146. The Court reasoned that the statute's requirement of specific intent to defraud alleviated the need to define the meaning of the term kosher comprehensively. See id. at 501-02. 
the First Amendment applied to the states. ${ }^{147}$ In recent years, two courts have struck down kosher fraud laws as violating the Establishment Clause $^{148}$ by creating excessive state entanglement with religion. ${ }^{149}$ Commentators differ over whether these laws actually violate the Constitution. ${ }^{150}$ Most troubling is the fact that the laws privilege Orthodox standards. All agree, however, that the state could not legislatively or judicially resolve inter-factional disputes about kashrut. ${ }^{151}$ Therefore, kosher fraud laws permit all good-faith claims of kashrut ${ }^{152}$ and cannot fully protect consumers' standards.

\section{B. Organic Food Laws}

State efforts to regulate organic labeling and advertising pre-date the federal government's efforts in that sphere. ${ }^{153}$ California, for example, prohibits the use of synthetic materials ${ }^{154}$ and provides for certain inspection and registration requirements. ${ }^{155}$ Its standards are fairly lax in some

147. See Cantwell v. Connecticut, 310 U.S. 296 (1940).

148. U.S. CONST. amend. I ("Congress shall make no law respecting an establishment of religion ....").

149. See Barghout v. Bureau of Kosher Meat \& Food Control, 66 F.3d 1337 (4th Cir. 1995); Ran-Dav's County Kosher, Inc. v. State, 608 A.2d 1353 (N.J. 1992).

150. Compare Stephen F. Rosenthal, Food for Thought: Kosher Fraud Laws and the Religion Clauses of the First Amendment, 65 GEO. WASH. L. REV. 951 (1997) (arguing that kosher fraud laws are constitutional), Shelley R. Meacham, Note.\& Comment, Answering to a Higher Source: Does the Establishment Clause Actually Restrict Kosher Regulations as Ran-Dav's County Kosher Proclaims?, 23 Sw. U. L. REV. 639 (1994) (arguing that consumer protection laws do not violate the Establishment Clause), Kristin Morgan, Casenote, The Constitutionality of New Jersey Kosher Food Regulations Under the Establishment Clause, 62 U. CIN. L. REV. 247 (1993) (arguing that the law at question in Ran-Dav's County Kosher was not facially invalid), and Sullivan, supra note 91, at 245 (concluding that "Ran-Dav was wrongly decided"), with Berman, supra note 89, at 2 (arguing that present laws violate the Establishment Clause and suggesting alternatives), Lindsay, supra note 141 (same), and Masoudi, supra note 95 (finding violations of both the Establishment and Free Exercise Clauses). Other commentators have staked out positions between these poles. See Greenawalt, supra note 105, at 809-10 (arguing that some state enforcement might be constitutional under certain circumstances); Stern, supra note 138, at 400 ("[T]here is a place for laws against kosher food fraud, but their compass is significantly smaller than current practice would indicate. ... [P]rimary responsibility for ensuring the kashruth of food belongs on the Jewish community itself.").

151. See, e.g., Greenawalt, supra note 105 , at 805 ("If the disputed instances are substantial, the New Jersey Supreme Court and the Fourth Circuit were rightly troubled by enforcement of Orthodox standards of kosher."); $c f$. Meacham, supra note 150, at 652 ("Application of a regulation is unconstitutional when it requires resolution of religious disputes ...."); Morgan, supra note 150 , at $277-8$ ("[R]esolution of disputes as to whether food is kosher has been characterized as an ecclesiastical dispute, which civil courts are forbidden to resolve."); Sullivan, supra note 91, at 239-240 ("The State refrains from enforcing the regulations to the extent that Orthodox Jewish authorities might dispute a particular requirement.").

152. This is exemplified by the fact that kosher fraud laws generally require specific intent. See Rosenthal, supra note 150, at 983 . The Supreme Court relied on this fact in the Hygrade decision. See supra note 146.

153. Gordon Bones cites regulations in 22 states. See Bones, supra note 14, at 408.

154. See Cal. Health \& SAFETY CODE $\$ 110,815$ (p)(1)(A) (West 1996).

155. See id. at $\$ \S 110,850,110,860$ (b) (West 1996 \& Supp. 1999). 
respects: Pesticides and fertilizers of "natural" origin may be freely used, ${ }^{156}$ and there are few other requirements to ensure the sustainability and ecological balance of the practices (irradiation is, however, prohibited). Nonetheless, the requirements are stricter in some ways than those of other states, such as Texas, which allow the regulated use of some synthetic materials. ${ }^{157}$

As the market for organic products expanded on the national and international scales, concern emerged that the lack of uniform standards would impede interstate commerce and therefore slow the industry's growth. ${ }^{158}$ Interestingly, it was largely mainstream agribusiness groups that provided the impetus for federal action; ${ }^{159}$ however, organic organizations soon joined the process to avoid losing their say on the outcome. ${ }^{160}$ In response, Congress passed the Organic Foods Production Act of $1990 .{ }^{161}$ The Act's stated purposes were "to assure consumers that organically produced products meet a consistent standard" and to facilitate interstate commerce in organic food, ${ }^{162}$ although its sponsors focused almost exclusively on the former. ${ }^{163}$ They argued that federal standards would eliminate consumer confusion ${ }^{164}$ by giving "growers and consumers ... a clear picture of just what organically grown really means." 165

156. See Bones, supra note 14 , at 413.

157. See id. at 412 .

158. See All Things Considered, supra note 45 (statement of Dan Glickman, Secretary of Agriculture).

159. See Bones, supra note 14, at 408 n.14; Felicia Busch, Organic Foods: What You See Is Not Necessarily What You Get, ENVTL. NUTRITION, July 1990, at 1 (noting that the United Fresh Fruit and Vegetable Association (UFFVA) led the demand for national legislation). The American Farm Bureau Federation also called for a national standard. See S. REP. No. 101-357, at 290 (1990), reprinted in 1990 U.S.C.C.A.N. $4656,4944$.

160. See Bones, supra note 14, at 409 n.14; John Mejia, Industry Develops Organic Definition, SUPERMARKET NEWs, July 24, 1989, at 19 (reporting on the worries of some that the UFFVA's task force on organic food, which did not include anyone from the organic industry, would not represent the best interests of the organic community). Today, most in the organic community generally applaud the idea of a National Organic Program. See, e.g., Clark, supra note 21, at 325 (calling the Organic Foods Production Act an "elegant and novel piece of legislation"). But see Demeter Letter, supra note 73, § 1.1, at 1 ("Farmers did not ask for federal regulation. Business interests did. . .business interests which want to make a buck by riding on someone else's initiative.").

161. Food, Agriculture, Conservation and Trade Act of 1990, Pub. L. No. 101-624, tit. XXI, 104 Stat. 3359,3935 (codified as amended at 7 U.S.C. $\$ \S 6501-22$ (1994)).

162. 7 U.S.C. $\$ 6501$ (1994). The Senate's version had also included "encourag[ing] environmental stewardship" and "provid[ing] market incentives to encourage the use of organic, sustainable farming methods," but this language was dropped without explanation by the congressional conference committee. See H.R. CONF. REP. No. 101-916, at 1174-75, reprinted in 1990 U.S.C.C.A.N. 5286, 5699-700.

163. See, e.g., 136 CONG. REC. 1796 (1990) (statement of Sen. Leahy); id. at 1811 (statement of Sen. Conrad). Speakers generally only hinted at the interstate commerce rationale. See, e.g., id. at 3078 (statement of Rep. DeFazio) (noting that it had become "extremely difficult to market products across State lines"). The Senate Report, by contrast, identified interstate commerce as a major factor. See S. REP. No. 101-357, at 289, reprinted in 1990 U.S.C.C.A.N. 4656, 4943.

164. See 136 CONG. REC. 33,890 (statement of Sen. Leahy).

165. Id. at 3078 (statement of Rep. DeFazio). 
The Organic Foods Production Act requires that all products sold or labeled as organic comply with standards promulgated by the Secretary of Agriculture, who establishes a list of approved and prohibited substances with advice from the National Organic Standards Board. ${ }^{166}$ The Act also provides for inspection, residue testing, and documentation. ${ }^{167}$ Although a state may establish its own programs with more restrictive requirements, any such requirements must "further the purposes" of and "not be inconsistent" with the Act. ${ }^{168}$ No state label may claim to be superior to the federal standards, however. ${ }^{169}$

The Department of Agriculture did not publish a proposed rule implementing the Act until December of $1997 . .^{170}$ Most of the rule's provisions were uncontroversial. However, the rule did not prohibit using treated municipal sewage sludge as a fertilizer, ${ }^{171}$ irradiation as a method of preserving foods, ${ }^{172}$ or genetically engineered foods. ${ }^{173}$ In its "most astonishing move," the rule forbade the use of other terms-such as "antibiotic-free" or "not genetically engineered"-on labels. ${ }^{174}$ Moreover, it prohibited private certifiers from requiring adherence to higher standards as a condition of certification. ${ }^{175}$

Upon learning of these proposals, the organic community was outraged. ${ }^{176}$ Organic farmers, who themselves would continue to abide by stricter standards, complained that the proposed definition would trivialize their products and destroy the market for organic food. ${ }^{177}$ Consumers argued that they would no longer be able to trust the organic label ${ }^{178}$-quite an irony for a program designed to increase consumer confidence.

166. See 7 U.S.C. $\$ \S 6505(a)(1), 6517(a), 6518(a)$. Synthetic materials may be included if they do not harm human health or the environment, do not have natural substitutes, and are consistent with organic practices. Id. $\S 6517(\mathrm{c})(1)(\mathrm{A})$. Natural substances may be banned for similar reasons. $I d$. $\S 6517$ (c)(2)(A). One commentator has noted that "Congress in essence gave the Secretary of Agriculture a blank slate on which to draft the meaning of ['organic']." Franzen, supra note 15 , at $401 \mathrm{n} .16$.

167. 7 U.S.C. $\$ 6506(a)$. id.

168. Id. $\S 6507(\mathrm{~b})$. The program must also be approved by the Secretary of Agriculture. See

169. See S. REP. No. 101-357, at 295 (1990), reprinted in 1990 U.S.C.C.A.N. 4656, 4949.

170. See National Organic Program, 62 Fed. Reg. 65,850 (1997).

171. See id. at 65,893 .

172. See id. at 65,884 .

173. See id. at 65,875 .

174. Hoffman, supra note 23 , at A23.

175. See National Organic Program, 62 Fed. Reg. at 65,952 (proposed 7 C.F.R. $\S 205.301(\mathrm{~b})(2))$.

176. See, e.g., IFOAM Letter, supra note 17, at 4-6 (arguing that genetic engineering, ionizing radiation, and municipal biosludge are all inconsistent with organic practice).

177. See, e.g., Hoffman, supra note 23, at A23.

178. See, e.g., Schiraga, supra note 39 (expressing concern that the federal standards were being set too low). 
Congressional opposition to the rule was significant. ${ }^{179}$ After receiving more than 275,000 written comments, ${ }^{180}$ the Department of Agriculture withdrew the proposal for further consideration. ${ }^{181}$

For the most part, it was not the fact of uniform federal standards itself that generated controversy, but merely the substance of those standards. Indeed, many simply urged the Department of Agriculture to follow the earlier recommendations of the National Organic Standards Board. ${ }^{182}$ This sequence of events demonstrates, however, the difficulty-if not impossibility - of devising a universally acceptable definition of organic food.

\section{International Trade Law}

For better or worse, ${ }^{183}$ free trade is a fact of international law under the General Agreement on Tariffs and Trade (GATT) ${ }^{184}$ and its side agreements. ${ }^{185}$ At its core, this regime is based on the principle of

179. See, e.g., 144 CONG. REC. H509 (daily ed. Feb. 24, 1998) (statement of Rep. Metcalf) (arguing that the rule was "both overreaching and inadequate"). Thirty-eight members of Congress urged the USDA to adopt stringent organic standards. See 144 CONG. REC. H4988 (daily ed. June 23, 1998) (statement of Rep. Kucinich).

180. See U.S. Dep't of Agric., National Organic Program Proposed Rule View Comments (visited Feb. 19, 1999) <http://www.ams.usda.gov/nop/view.htm > (listing comment figures). The Department of Agriculture received more comments on its proposed organic rule than any other government agency has ever received on any public issue. See Hobbs, supra note 17, at C1.

181. See U.S. Dep't of Agric., USDA To Make Fundamental Changes in Revised Proposed Rule on Organic Standards (visited Nov. 30, 1998) <http://www.ams.usda.gov/news/orgrule.htm> (reprinting a May 8, 1998 news release that announced the withdrawal). The USDA recently announced that it will allow meat and poultry to be labeled organic while federal standards are developed. See Marian Burros, U.S. To Allow Organic Label on Some Meats and Poultry, N.Y. TIMES, Jan. 15, 1999, at A20. Previously, federal labeling regulations had precluded such claims. See id.

182. See, e.g., Hoffman, supra note 23, at A23 (asking that the proposed rule "be scrapped and rewritten in accordance with the original recommendations by the national standards board ...."). But see Michael Colby, USDA's Organic Standards Rejected but the Fight's Not over, EARTH ISLAND J., Summer 1998, at 42 ("The ultimate certifier for food products should not be the federal government, but rather a relationship of trust among producer, consumer and community.").

183. Compare Jagdish Bhagwati, The Case for Free Trade, SCI. AM., Nov. 1993, at 42 (arguing that free trade produces revenue for environmental protection and encourages efficient use of resources), with Herman E. Daly, The Perils of Free.Trade, SCI. AM., Nov. 1993, at 50 (arguing that there is a clear conflict between free trade and sound environmental policy). For a recent overview of trade law and environmental issues, see EDITH BROWN WEISS ET AL., INTERNATIONAL ENVIRONMENTAL LAW AND POLICY 1035-1102 (1998).

184. Oct. 30, 1947, 61 Stat. A-11, T.I.A.S. 1700, 55 U.N.T.S. 194 [hereinafter GATT]. See also Final Act Embodying the Results of the Uruguay Round of Multilateral Trade Negotiations, Apr. 15, 1994, LEGAL INSTRUMENTS-RESULTS OF THE URUGUAY ROUND vol. 1 (1994), 33 I.L.M. 1125 (1994).

185. The two most relevant to ecolabels are the Technical Barriers to Trade and the Sanitary and Phytosanitary Measures agreements. The Technical Barriers to Trade agreement mandates that all regulations-including labeling requirements-be based on international standards, where possible, and least trade-restrictive. See Agreement on Technical Barriers to Trade, Dec. 15, 1993, Marrakesh Agreement Establishing the World Trade Organization, Annex 1A, LEGAL 
nondiscrimination: ${ }^{186}$ Imports from party nations must be treated no less favorably than "like products" produced in any other nation ${ }^{187}$ or domestically. ${ }^{188}$

In a number of controversial cases, GATT dispute resolution panels have determined that products are considered "like" if they share physical characteristics; conversely, production and processing methods may not be used to differentiate products. ${ }^{189}$ For example, the United States could not require all tuna sold in this country to be "dolphin safe," because the method of catching the fish does not affect the product itself..$^{190}$ The concern is that environmental regulations, although perhaps having legitimate bases, will be used as unilateral "protectionist" trade barriers. ${ }^{191}$

This holding alone would suggest that any government labeling program that employed production and processing methods not affecting the product would violate the GATT. But surprisingly, several GATT panels have seemed to indicate that voluntary labeling schemes would be acceptable. ${ }^{192}$ This murky jurisprudence ${ }^{193}$ leaves organic and kosher ${ }^{194}$

INSTRUMENTS-RESULTS OF THE URUGUAY ROUND vol. 27 (1994). Health standards are covered by the Sanitary and Phytosanitary Measures agreement, which requires all standards to be necessary, based on scientific evidence, and least trade-restrictive. See Agreement on the Application of Sanitary and Phytosanitary Measures, Dec. 15, 1993, Marrakesh Agreement Establishing the World Trade Organization, Annex 1A, LEGAL INSTRUMENTS-RESULTS OF THE URUGUAY ROUND vol. 27 (1994).

186. See DANIEL C. ESTY, GREENING THE GATT 245 (1994).

187. See GATT art. I. This is known as the most-favored nation provision. See ESTY, supra note 186 , at 245 .

188. See GATT art. III. This is the national treatment provision. See ESTY, supra note 186, at 246. There are limited exceptions to the article I and III requirements, including actions necessary for the protection of human, animal, or plant life or health, or related to the conservation of exhaustible natural resources. See GATT art. XX. These exceptions have been construed narrowly. See David M. Parks, GATT and the Environment: Reconciling Liberal Trade Policies with Environmental Protection, 15 UCLA J. ENVTL. L. \& POL'Y 151, 156 (1996-97).

189. See, e.g., GATT Dispute Settlement Panel Report on U.S. Restrictions on Imports of Tuna, 33 I.L.M. 839, 889-90 (1994) (Tuna II).

190. See United States Restrictions on Imports of Tuna, GATT B.I.S.D. (39th Supp.) at 155, 195 (1993) (Tuna I) (report not adopted by the Council).

191. Cf. Dawkins, supra note 5, at 503 (" $[$ P]roblems include ... biased criteria setting, with most of the programs designed in the importing countries with the participation of domestic competitors according to domestic perceptions of environmental issues."); id. at 504 ("As ecolabelling becomes a matter of international policy, decisive inputs from captured institutions could jeopardize its viability as effective public policy. Indeed, in such a case, many producers may regard ecolabelling as a restrictive business practice with some legitimacy ...."); Franzen, supra note 15 , at $401 \mathrm{n} .16$ ("Since the board advising the Secretary consists of members from the domestic organic food industry, it is highly probable that the final rules will favor the domestic methods.").

192. See, e.g., European Community-Measures Concerning Meat and Meat Products (Hormones), WT/DS26/R, para. 8.274 (June 30, 1997) (dictum) (" [T] he ability of any Member to enact measures which are intended to protect not consumer health but other consumer concerns was not addressed. In this regard, we are aware that in some countries . . . voluntary labelling schemes operate ...."), aff d in part, modified in part, and rev'd in part, WT/DS26/AB/R (Feb. 13, 1998); Tuna I, GATT B.I.S.D. (39th Supp.) at 203 ("Any advantage which might possibly result from access to [the dolphin-safe] label depends on the free choice by consumers ...."). One commentator has noted that the Tuna I panel only addressed the most-favored nation 
regulatory laws in limbo. ${ }^{195}$ There appears to be agreement, however, that privately run programs would pass muster. ${ }^{196}$ In the next Part, I will discuss the prospects for such programs in greater detail.

\section{HARNESSING MARKET FORCES TO REgULATE KOSHER AND ORGANIC FOOD}

Most commentators have assumed that government regulation is the only, or at least the best, way to protect consumers and ensure that kosher and organic standards are upheld. Yet public regulation alone fails to preserve the ethical pluralism that characterizes both the kosher and organic communities $^{197}$ and thereby may run afoul of constitutional values and international law. I argue in this Part that there is an alternative: The market can dictate the standards in an inclusive manner. A model-what I refer to as a private-public hybrid-has been developed in the kosher market. In Section III.A, I examine this model and explain how it accommodates

requirement of the labeling program, and has suggested that the panel's failure to consider the national treatment requirement lead to its approving the scheme. See Erik P. Bartenhagen, Note, The Intersection of Trade and the Environment, 17 VA. ENVTL. L.J. 51, 65-67 (1997).

193. Compare id. at 67-68 (concluding that "all but a handful" of ecolabeling programs could be invalidated), with Samuel N. Lind, Eco-Labels and International Trade Law: Avoiding Trade Violations While Regulating the Environment, 8 INT'L LEGAL PERSP. 113, 140-41 (1996) (concluding that government-sponsored voluntary programs are generally valid), and Staffin, supra note 136, at 266 (same). The Committee on Trade and Environment, formed by the World Trade Organization, has issued a thorough but inconclusive report on the subject. See Bartenhagen, supra note 192, at 78 .

194. That these are state, rather than federal, laws should not matter. See generally James T. O'Reilly, Stop the World, We Want Our Own Labels: Treaties, State Voter Initiative Laws, and Federal Pre-emption, 18 U. PA. J. INT'L ECON. L. 617 (1997) (arguing that the GATT might preempt some state labeling requirements).

195. Two commentators have concluded that the Organic Foods Production Act of 1990 violates the GATT and its side agreements. See Terence J. Centner, The United States's Organic Foods Production Act: Does the Small-Farmer Exception Breach the United States's Obligations Under GATT?, 28 TULSA L.J. 715, 722 (1993) (concluding that it does violate the GATT); Franzen, supra note 15, at 428-29 (concluding that the OFPA violates article III of the GATT). The kashrut situation does not appear to have been discussed in the literature. The free trade agreement between the Unites States and Israel specifically allows for kashrut regulations. See Free Trade Area Agreement, Apr. 22, 1985, Isr.-U.S., art. 8, 24 I.L.M. 653, 659. It is unlikely that any domestic kosher fraud laws would be challenged under the GATT, however, since they are not generally enforced in controversial cases; if they were, domestic courts would likely hold them unconstitutional. See supra notes 148-152 and accompanying text.

196. See Lind, supra note 193, at 134-35. But see Veena Jha \& Simonetta Zarrilli, EcoLabeling Initiatives as Potential Barriers to Trade, in ORGANISATION FOR ECON. COOPERATION \& DEV., LIFE-CYCLE MANAGEMENT AND TRADE 64, 71 (1994) (suggesting that a state might be held responsible for tacitly approving private ecolabeling programs).

197. In theory, the government might establish separate certification programs for each specific set of values. For example, putting aside First Amendment concerns, kashrut standards could be established for Orthodox, Conservative, Ashkenazic, Sephardic, glatt, "Jewish milk" (i.e., milk produced only by Jews; see supra note 107), and all of their various permutations, as a start. The administrative costs of any such proposal, however, are likely to be very high: Each different standard would have to be formulated, enforced, disseminated, and updated regularly. 
heterogeneous standards. I argue in Section III.B that it should serve as a paradigm for organic food, despite differences between the kosher and organic markets.

\section{A. Private Kashrut Supervision}

In the United States, the "laws" of kashrut are, for the most part, privately enforced.$^{198}$ Religious organizations, national and local, ${ }^{199}$ contract with food producers to supervise production and then certify the finished products as kosher. ${ }^{200}$ The supervising organization often has a trademarked symbol that appears on the labels of approved products. ${ }^{201}$ Consumers, in turn, choose to purchase foods certified by organizations that they trust. ${ }^{202}$ The largest of these organizations, the "OU," ${ }^{203}$ certifies products in fiftyfour countries, ${ }^{204}$ and accounts for approximately seventy percent of the certified products in the United States. ${ }^{205}$ Today, there are more than 200 registered kashrut symbols used in this country. ${ }^{206}$

198. See Greenawalt, supra note 105 , at 787-88. Few prosecutions have been brought under kosher fraud laws. See Sullivan, supra note 91, at 211-12; cf. Stern, supra note 138, at 399 ("The kosher food laws are not "Blue Laws," nor ... would they permit the State to act as a guarantor of the kashruth of an establishment in the way that the Union of Orthodox Jewish Congregations does.").

199. See Berman, supra note 89 , at 11-12. National organizations generally supervise only large food producers with wide distribution, and local establishments usually receive local supervision. See id.

200. Cf. Genack, supra note 99, at 404 ("Each company which receives OU supervision adheres to kashrut regulations which are established in a contract between that company and the OU."); Masoudi, supra note 95, at 695 ("Private rabbinical organizations allow the use of their symbols through contract; any dispute between a purveyor of kosher food and such an organization could be resolved as a contractual dispute, with matters of religious faith left to the parties to the contract to resolve.").

201. See Regenstein \& Regenstein, supra note 82 , at 415 (describing some of the well known symbols). The symbol indicates that the product meets that organization's definition of kashrut. See Masoudi, supra note 95 , at 695 . The letter " $K$ " by itself cannot be trademarked, and so may be used by anyone. See Genack, supra note 99, at 403. New York requires all kashrut symbols, including $\mathrm{K}$, to be backed by a registered rabbi or supervising agency. See id. The conventional wisdom in the Orthodox community is that a plain $\mathrm{K}$ is not generally acceptable. Nevertheless, for strategic reasons, some producers use a $\mathrm{K}$ even when a national organization is supervising-it is much easier to switch supervision if the labeling need not be redesigned. See Regenstein \& Regenstein, supra note 82, at 421-22; cf. EIDLITZ, supra note 97, at 11 (noting that Kraft products carry a $\mathrm{K}$ even though they are supervised by the nationally recognized " $O K$ ").

202. See Schwartz, supra note 104 , at 427.

203. The Union of Orthodox Jewish Congregations of America is known colloquially as the "OU" for its certification symbol, a circle with a U in it. See Genack, supra note 99, at 403.

204. See Rona S. Hirsch, Cutting a Deal: A Local Kosher Butchery Bows to Pressure from Vaad HaKashrus Kosher Certification Organization, BALT. JEwISH TIMES, Mar. 28, 1997, at 18; cf. Linda Habenstreit, What's To Nosh? A Growing Niche Market for Kosher Foods, That's What, AGEXPORTER, Sept. 1998, at 4 (noting that American certifications are accepted in many countries).

205. See Berman, supra note 89 , at 12.

206. See SCHLOSSBERG, supra note 90 , at 52 . 
Each organization sets its own standards, based on the practices of the particular demographic group whose recognition it seeks, and contracts with producers to follow whatever procedures it deems necessary to enforce these standards. In fact, the standards need not necessarily be limited to the strict parameters of kashrut but can address any other issues of concern to the Jewish community. ${ }^{207}$ The system is based on trust, and the often closeknit religious communities ${ }^{208}$ in this country can be quite unforgiving about actual or rumored lapses. ${ }^{209}$

Kashrut organizations expend a great deal of effort to build trust through providing information; this is supplemented by publicity from many other religious organizations that care about the observance of Jewish law. ${ }^{210}$ Consumers also self-inform and rely on the reputations of particular kashrut organizations. For example, Ashkenazic Jews avoid purchasing food for Passover that is under Sephardic supervision because of concerns about legumes and rice. ${ }^{211}$ Similarly, many Orthodox Jews carefully scrutinize candies from Israel because of concerns about gelatin. ${ }^{212}$

207. For example, the Star-K, a highly reputable organization run by Baltimore's rabbinical council, ordered a boycott of a local butcher who used the New York-based OU for supervision. See Hirsch, supra note 204. The issue was not one of kashrut-the council permitted the use of OU-certified meats in other contexts-but rather ensuring the integrity of local religious authority. See id. Certifiers also commonly require Sabbath adherence. $C f$. Cohen v. Silver, 178 N.E. 508 (Mass. 1931) (refusing relief to a wholesaler who was denied a permit to sell kosher meat by local rabbinical authorities because he violated the Sabbath and refused to appear before a religious court); HAROLD P. GASTWIRT, FRAUD, CORRUPTION, AND HOLINESS 136-37 (1974) (discussing a New York case where the defendant prevailed after being prosecuted for selling meat on the Sabbath); Stern, supra note 138, at 399 (noting that kashrut supervisors, but not state authorities, might appropriately require producers to adhere to the laws of Sabbath). This requirement can be justified instrumentally (e.g., that Sabbath observance is necessary to enable constant supervision, since a non-Sabbath observer could not be trusted to enforce the standards adequately) or intrinsically (i.e., kashrut represents a larger ethical worldview, one inconsistent with nonobservance of the Sabbath). A final example is provided by Bazooka Gum, certified by the OU. Concerned that the gum's accompanying comic strip "may reflect ideas that are not in keeping with Judaism," the OU secured changes to its content. See Consumer Alert 68, KASHRUS MAG., Feb. 1996, at 16.

208. This, of course, can lead to problems for consumers outside of these circles who do not maintain these contacts. See, e.g., Sullivan, supra note 91, at 243-44; cf. Rona S. Hirsch, Kosher Cooperation: A Local Kosher Certification Group Promises To Notify Non-Orthodox Leaders When Kosher Crises Surface, BALT. JEWISH TMIES, May 1, 1998, at. 1 (describing a plan to disseminate information on kashrut issues via posted notices and pulpit announcements).

209. See Berman, supra note 89 , at 12.

210. Cf. Greenawalt, supra note 105 , at 787-88 ("Local rabbis inspect stores and restaurants and guide followers about which of those observe kosher requirements."). An example of disseminated information is Kashrus Magazine, published five times a year by Yeshiva Birkas Reuven. In its "Consumer Alert" section, it provides information about unauthorized use of kashrut symbols, mislabeled products, and the supervision industry generally. See, e.g., Consumer Alert, KASHRUS MAG., Feb. 1996, at 6.

211. See, e.g., Pesach Consumer Alert 22, KASHRuS MAG., Apr. 1995, at 10 (warning Ashkenazic customers to avoid relying on information in Sephardic Passover directories).

212. See, e.g., Pesach Consumer Alert 20, KASHRus MAG., Apr. 1995, at 10 (waming consumers that some Elite products sold in Israel contain gelatin). 
This enforcement regime, however, also relies on public law. Private litigation (or its threat) provides an important tool for kashrut supervisors. Supervisory organizations zealously protect their trademarks, which form the basis of consumer trust. ${ }^{213}$ Contract law can also serve as a basis for enforcement. $^{214}$

The state can play a valuable role in other ways, through mandatory disclosure requirements, handling verification, and fraud prosecution. New Jersey, for example, requires disclosure of "the basis upon which [the] representation is made" that a product is kosher. ${ }^{215}$ In a similar vein, New York requires all certifiers to register with the state. ${ }^{216}$ The government might be in a better position to ensure proper handling of foods after production but before sale; for example, private groups might certify the slaughtering but rely on government regulations to ensure that the proper meat is distributed to customers. ${ }^{217}$ Some commentators have suggested that certain types of fraud prosecutions-based on objectively verifiable claims rather than value-laden religious labels-might properly fall within the realm of government enforcement. ${ }^{218}$ In fact, many kashrut organizations

213. See, e.g., Levy v. Kosher Overseers Ass'n of Am., 104 F.3d 38 (2d Cir. 1997) (involving an effort by $\mathrm{OK}$ to seek an injunction to prevent the use of a half-moon-K on the grounds that it could be confused with its circle-K); Storck USA, L.P. v. Levy, No. 90 C 5382, 1991 WL 244535 (N.D. Ill. Nov. 13, 1991) (involving a suit by OK for unauthorized use of ts symbol). For a critical analysis of the former case, see Jack Achiezer Guggenheim, KOA Is A.O.K.: The Second Circuit's Recent Kosher Trademark Decision Further Illustrates that the Patent and Trademark Office Must Answer to a Higher Authority, 22 ColUM.-VLA J.L. \& ARTS 203,213 (1998), which asserts that kosher consumers are "sophisticated" and therefore unlikely to be confused by similar marks.

214. Cf. Ran-Dav's County Kosher, Inc. v. State, 608 A.2d 1353, 1366 (N.J. 1992) ("The enforceability of [mandatory disclosure requirements] would inhere in the notion that they simply would compel [the merchant] to perform a secular obligation to which he contractually bound himself by virtue of the fact that merchant represents food as being kosher." (citation and internal quotation marks omitted) (first alteration added)). A stark example of how this works in practice is the supervision of kosher foods produced in China. See Craig S. Smith, This Rabbi's Mission: Making Sure China Is Keeping It Kosher, WALL ST. J., Dec. 3, 1998, at Al (describing the efforts of a Canadian Hassidic rabbi to ensure strict adherence to kosher standards in a Chinese factory).

215. N.J. STAT. ANN. § 56:8-63 (West Supp. 1998). This approach was suggested by the New Jersey Supreme Court. See Ran-Dav's County Kosher, 608 A.2d at 1365. Similar statutes have been proposed by commentators. See, e.g., Berman, supra note 89, at 71-72 (describing a model "Kosher Labeling Law"). A failed federal bill proposed in 1990 would have required disclosure for any religious food claims (which, in addition to kashrut, would have covered Muslim halal standards). See Public Disclosure of Religious Dietary Certification Act, H.R. 5447, 101st Cong. (1990).

216. See N.Y. AGRIC. \& MKTS. LAW § 201-e(3) (McKinney 1991). This requirement includes the non-trademarked K. See id. at $\S 201-\mathrm{e}(3-\mathrm{a}) ;$ cf. supra note 201 (discussing the status of the plain $\mathrm{K}$ in the kosher community).

217. See Greenawalt, supra note 105 , at $788 \mathrm{n} .31$.

218. For example, Kent Greenawalt compares state enforcement of supervision claims to the claim that a cross was "Personally Blessed by the Pope," a claim that has objective meaning even in a strictly secular society. See id. at 790. Gerald Masoudi makes a similar distinction between a claim that "a vial of water has come from the Dead Sea" and "the vial of water [has] been declared by God to be healing water." Masoudi, supra note 95 , at 690 . 
refer matters of fraud to state authorities, and thus serve as informal kashrut investigators. ${ }^{219}$

This private-public hybrid allows the market to determine kashrut standards. In fact, hundreds of certifiers compete, supervising different definitions of kosher for various segments of the community. Private companies also can respond to market preferences rapidly and efficiently; governments, by contrast, are often slowed by formal procedures and bureaucratic inertia.

\section{B. Applying the Kosher Model to Organic Food}

The kosher and organic communities share a key featureheterogeneity - and the kosher market has solved the difficulties that this poses by resorting to a private-public hybrid enforcement regime. I argue in this Section that the same policies ought to be pursued in the organic market.

\section{Organic Certification Organizations}

Over thirty-three private organic certification organizations exist in this country, covering a wide range of products. ${ }^{220}$ Like their kashrut counterparts, these organizations work on different geographic scales and cater to diverse sectors of the organic community. For example, the Demeter Association, which certifies biodynamic and organic farms, is highly respected in the general organic community. ${ }^{221}$ In keeping with the organic emphasis on local production and consumption, many of these organizations confine their activities to limited regions. The Northeast Organic Farming Association, a federation of seven independent state chapters, exemplifies this behavior. ${ }^{222}$ Nevertheless, general standards are often developed on a larger scale. Groups such as the internationally respected International Federation of Organic Agriculture Movements accredit certification organizations that meet their requirements. ${ }^{223}$ This process allows smaller organizations to draw on the credibility of a known authority while retaining the degree of autonomy necessary to function

219. See, e.g., Jonathan Slonim, Kosher Certifiers Say Violations Are on the Rise, FORWARD, June 27, 1997, at 2 (" [A]n OU representative[ said more than 100 instances of fraudulent mislabeling had been reported to the OU last year, some even forcing the OU to resort to court action.").

220. See National Organic Program, 62 Fed. Reg. 65,850, 65,914 (1997) (proposed 7 C.F.R. pt. 205).

221. See supra note 77. Demeter also certifies organic farms in transition to, but not yet, biodynamic. See Demeter Letter, supra note 73, at 1.

222. See NOFA Interstate Home Page (visited Feb. 15, 1999) <http://www.nofa.org>.

223. See IFOAM Letter, supra note 17, at 9. 
effectively. Accreditation also preserves some separation between the formulators and implementers of organic standards, which may provide a structural check against gross abuses. ${ }^{224}$ The details of the relationship are contractual and therefore negotiable.

In this regime, the market sets organic standards. Consumers define the term "organic" by purchasing food that meets their ethical concerns. ${ }^{225}$ For example, a consumer solely interested in the health benefits of organic food might not be interested in whether the food was also produced in accordance with the U.N. Human Rights Charter; other consumers, however, might see this as essential to their decision to purchase organic. ${ }^{226}$ These differing preferences could be accommodated by two certification organizations, one focusing only on health issues and one addressing broader factors. ${ }^{227}$

Ultimately, this system depends on consumers' trust of the certification process. Organic producers currently sell directly to local consumers largely on the basis of a trust relationship. ${ }^{228}$ By adopting the standards of IFOAM or another authority, a certifier could begin to establish this relationship with the larger public. ${ }^{229}$ Of course, it would be free to establish its own standards, in accordance with whatever values it thinks desirable. Internet sites, which allow an organization to publicize easily the details of its policies, provide another opportunity to build consumer loyalty. ${ }^{230}$ In fact, the certification seal could include the address of the organization's Web site, which would allow concerned consumers to obtain more information

224. See Letter from Farm Verified Organic, Inc. to Lisa Grove \& Don Hulcher 2 (Jan. 15, 1998) (on file with The Yale Law Journal) [hereinafter Farm Verified Organic Letter]; IFOAM Letter, supra note 17 , at 9.

225. Although the Establishment Clause concerns in the domain of kashrut, see supra notes 148-151 and accompanying text, do not apply with the same force to organic foods, I would argue that their spirit should counsel similar governmental restraint in this case.

226. Cf. supra text accompanying note 49 (quoting IFOAM's definition of organic, which includes human rights concerns).

227. One organization could also administer two separate organic programs with separate seals. Indeed, the Demeter Association certifies both biodynamic and organic farms. See supra text accompanying note 221 .

228. See Brian Halweil, USDA Organics, 100\% Farmer-Free, WORLD WATCH, Mar/Apr. 1998, at 2 (noting that in the "face-to-face commerce of farmers' markets and communitysupported agriculture ... mutual trust typically supersedes regulation").

229. See Mort Mather, What Is Organic Food?, MoTHER EARTH NEwS, Aug./Sept. 1998, at 34. Some of IFOAM's standards are discussed supra text accompanying note 49.

230. See, e.g., California Organic Certified Farmers, Certification Standards (visited Jan. 1, 1999) <http://www.ccof.org/certification_standards.htm>. Kosher organizations, too, have begun to take advantage of the new information technologies. For example, the OU now posts updates on the kashrut of products on the Web, and even e-mails them to consumers. See Orthodox Union, 5759 OU Kosher Alerts (visited Feb. 19, 1999) <http://www.ou.org/kosher/alerts>. 
without overwhelming other purchasers with details. A certifier would also benefit from a reputation for vigilant and uncompromising enforcement. ${ }^{231}$

In addition, other members of the organic community can help to police the certifying organizations. Some of these organizations operate on a nonprofit basis. Volunteers are crucial to the success of many certifiers. ${ }^{232}$ These people have a stake in the integrity of the certification process. They can be expected to help disseminate information about practices to other organic producers and consumers, much in the same way that rabbis and other community leaders do in the kosher market.

\section{Kosher and Organic Markets Compared}

Is the organic community strong enough to be self-regulating, as the kosher market is? The kashrut regime, after all, builds on the close-knit community already created through a shared religion. A hint of analogous structure in the organic community, however, may be gleaned from the way a record number of people were mobilized to respond to the USDA's proposed rule. ${ }^{233}$ In particular, more than half of the comments came as form letters distributed by various organizations. ${ }^{234}$ These numbers show that organic consumers read organic magazines, ${ }^{235}$ belong to organic food cooperatives, ${ }^{236}$ shop at organic markets, ${ }^{237}$ and even share long distance and credit card companies. ${ }^{238}$ Most importantly, this diffuse network functioned as a source of information about the proposed rule. It is thus conceivable that organic consumers see themselves as sharing a common identity with others who make the same choices.

Moreover, it is not necessary that every organic consumer be fully informed and conscientious. A core, committed group may be able to protect standards for the whole industry, because it is these consumers who

231. Cf. Demeter Letter, supra note $73, \S 1.2$, at 2 ("Consumers are accustomed to looking for certain seals and logos and find their use valuable for making an informed choice of products.").

232. See id. $\S 1.1$, at 1 (claiming that farmers have contributed "thousands of hours of volunteer labor" to develop organic standards and certification programs); Farm Verified Organic Letter, supra note 224, at 3 (noting the "enormous amount of volunteer work" that drives the certification industry).

233. See supra note 180.

234. See U.S. Dep't of Agric., supra note 180.

235. More than 17,000 readers of Organic Gardening submitted the comment that the magazine had printed. See U.S. Dep't of Agric., Form Letter Page (visited Mar. 3, 1999) $<$ http://www.ams.usda.gov/nop/forms.htm $>$.

236. For example, the Onion River Food Co-op in Burlington, Vermont, generated nearly 1,000 comments. See id.

237. For instance, nearly 1,000 customers of the Harvest Cooperative Supermarkets in the Boston area commented. See id.

238. More than 35,000 customers of Working Assets, a socially responsible firm that offers long distance and credit card services, submitted comments. See id.; cf. Working Assets (visited March 11, 1999) <http://www.wald.com>. 
are most likely to be reliable organic purchasers, and hence the most desirable constituency for producers and certifiers. In other words, organic producers will tend to target their products to the most loyal segment of the market. One example of such a core group might be biodynamic practitioners, who adhere to extremely rigorous organic standards. Compare this with kashrut: Orthodox Jews constitute a small minority of kosher consumers, but the vast majority of certification organizations adhere to Orthodox standards. ${ }^{239}$

There are, to be sure, significant differences between the kosher and organic communities. One might argue that religious beliefs run deeper than environmental ethics and that rabbis therefore would be (or at least would seem) more trustworthy than organic certification organizations. It is important to note, however, that profits and business drive some (but not all) motivations in both industries. Indeed, kosher consumers' strong skepticism of many certification marks is evidence that mere religious ties are not enough to ensure integrity. The sense of community is crucial to the kosher and organic markets, and there are opportunities to build it in both.

\section{The Role of Government}

As with kashrut, there is ample room for government action in the organic regime. At a minimum, contract and trademark laws enable private certifiers to enforce their standards. But public law might also promote information, research, and education. ${ }^{240}$ In particular, a mandatory disclosure requirement, in the same vein as New Jersey's kashrut law, ${ }^{241}$ would facilitate a system of private certification. In fact, a uniform federal disclosure-law might beneficially preempt inconsistent state regulations, thereby promoting freer trade of organic food. ${ }^{242}$

Fraud laws also play an important role in policing private certification. Producers who use objectively false labels can be prosecuted. Thus, for example, it would not be problematic for the government to enforce a "non-

239. See, e.g., Feigenbaum, supra note 87, at 20 (noting that only one region of the Rabbinical Assembly in the world provides "formal Conservative kashrut supervision.") An analogous effect has been noted with respect to automobile emission standards: Historically, California's lower permitted levels have been met by manufacturers and then become the basis for new, stricter federal standards. See DAVID VOGEL, TRADING UP: CONSUMER AND ENVIRONMENTAL REGULATION IN A GLOBAL ECONOMY 259 (1995) (describing the "California effect").

240. See, e.g., IFOAM Letter, supra note 17, at 11 (suggesting that government policy be directed toward "environmental and resource conservation, rural development, and agricultural research").

241. See supra text accompanying note 215 .

242. Cf. supra text accompanying notes 158 \& 162 (discussing the interstate commerce rationale for uniform organic standards). 
irradiated" label..$^{243}$ Specific, verifiable claims, then, would subject a certification to more exacting oversight. As mentioned above, the need to build trust is likely to drive certifiers to make their standards transparent and detailed; ${ }^{244}$ in this way, fraud laws can foster trust. Organizations are in fact starting to make more specific claims: For example, "Salmon Safe" agriculture, "Turtle Safe Shrimp", and "Predator Friendly Wool" labels now replace or supplement the organic label on some products. ${ }^{245}$

Finally, there would be less reason for concern about a mandated "baseline" standard, which established minimum requirements for an organic label. If all (or the vast majority) of organic producers and consumers agreed on some principles, such as prohibiting all use of synthetic pesticides, the government might appropriately consider these to be incorporated into the meaning of organic. Of course, this approach would still allow for a great deal of variance among certification standards, as an organization could choose to require more than the government minimum. In fact, this has been the approach of many states, including the successful California organic program. ${ }^{246}$

Organic consumers are, like kosher consumers, capable of exercising a healthy degree of skepticism about unsubstantiated claims. Eliminating their right to make ethical choices in the name of consumer protection is bad policy and ultimately detrimental to the burgeoning organic industry.

\section{CONCLUSION}

The proposed federal rule failed to "tak[e] into account the fundamental principles and practices of organic agriculture and [to] consider[ $]$ the international context" ${ }^{247}$ in which organic food production occurs. More seriously, however, it effectively would have destroyed the burgeoning certification regime by mandating uniformity. This provision, designed to facilitate interstate and international commerce by fully harmonizing all requirements, sacrificed the ethical pluralism that makes the kosher certification regime so effective. In doing so, it stifled claims).

243. Cf. supra text accompanying note 218 (discussing a similar situation with religious

244. See supra text accompanying notes 229-231.

245. See Daniel Imhoff, Beyond Organic: Farming with Salmon, Coyotes, and Wolves, SIERRA, Jan./Feb. 1999, at 24.

246. See Bones, supra note 14, at 411 (noting that California's program requires only limited state involvement); $i d$. at 417 (noting California's reliance on private certification organizations).

247. IFOAM Letter, supra note 17, at 2 . The letter also notes that the rule borrowed the riskassessment techniques used in mandatory programs and inappropriately applied them to the voluntary, organic program. See id. at 3 ("[T]he Proposed Rule would actually promote the deterioration of ecosystems by requiring proof [of environmental degradation]. ... The organic system, in contrast, seeks to avert damages before they occur.") 
innovation, ${ }^{248}$ created perverse incentives for the industry, ${ }^{249}$ and ran afoul of international law.

It is easy for those concerned about confusion and uniformity to propose a regulatory solution, but such a policy can impair ethical decisionmaking. Privately driven certification, on the other hand, promotes the health of the kosher and organic markets: It continuously forces producers and consumers to reevaluate their commitments and pay close attention to the food that they eat-thereby serving the ultimate goals of both systems.

248. See id. at 7 (arguing that the right to set higher standards "permits timely responses to the development of new consumer demands" and "is the motor for continuous improvement and innovation of the organic guarantee system through fair competition in the marketplace").

249. Fixed standards mean that a competitive advantage is given to those producers who do only the bare minimum but still collect the full premium. Heterogeneous standards, by contrast, allow certifiers to publicize their differences and compete for the loyalities of both consumers and producers. 